Rev. Int. Contam. Ambie. 38, 57-80, 2022

https://doi.org/10.20937/RICA.54132

\title{
FINE PARTICLES EMISSION SOURCE PROFILES FOR A SEMI-ARID URBAN CENTER: KEY MARKERS AND SIMILARITY TESTS
}

Perfiles de emisión de partículas finas para un centro urbano en una región semi-árida: marcadores clave y pruebas de similitud

\section{Yasmany MANCILLA, Gerardo MEDINA, Lucy T. GONZÁLEZ and Alberto MENDOZA*}

Escuela de Ingeniería y Ciencias, Tecnológico de Monterrey, Av. Eugenio Garza Sada 2501, 64849 Monterrey, Nuevo León, México.

*Author for correspondence: mendoza.alberto@tec.mx

(Received: September 26, 2020; accepted: September 3, 2021)

Key words: carbonaceous aerosol, chemical fingerprints, emissions characterization, near-field sampling, particulate matter

\begin{abstract}
Source apportionment studies rely on source emission profiles, which in some instances are locally scarce or non-existent. Thus, estimations are done using profiles obtained from other geographical sites, which brings a certain degree of uncertainty in the outcomes of such studies. This work presents the results of near-field measurement of 12 types of fine particle emission sources to develop local-region source profiles in the Monterrey Metropolitan Area. The source profiles include a chemical characterization of trace elements and carbonaceous fraction. A statistical analysis based on the Pearson distance and similarity identity distance was conducted to ensure the uniqueness of each source profile. Overall, the most dominant species in the profiles were organic and elemental carbon, and elemental sulfur, whereas the least abundant were transition metals. The meat-cooking operations profiles exhibited the highest organic carbon to elemental carbon ratios, which were 7-40 times higher than those for biomass burning and vehicle exhausts profiles. The urban construction profile was dominated by crustal elements, while the suburban area profile exhibited an internal mixing with anthropogenic compounds. The source profiles in this study were distinguishable, as determined by preliminary tests for each pair of chemical source profiles. These profiles could be used to implement receptor models in urban sites with similar characteristics.
\end{abstract}

Palabras clave: aerosol carbonáceo, huellas químicas, caracterización de emisiones, muestreo en campo cercano, partículas suspendidas finas

\section{RESUMEN}

Los estudios de atribución de fuentes se basan en perfiles de emisión de fuentes que en algunos casos son escasos o inexistentes; por lo tanto, las estimaciones se realizan utilizando perfiles obtenidos de otros sitios geográficos, lo que genera un cierto grado de incertidumbre en sus resultados. Este trabajo presenta los resultados de una medición en campo cercano de 12 tipos de fuentes de emisión de partículas suspendidas finas, con el fin de desarrollar perfiles para fuentes ubicadas en el Área Metropolitana de Monterrey. Los perfiles de emisión incluyen una caracterización química de elementos 
traza y la fracción carbonácea de las partículas. Se realizó un análisis estadístico basado en la distancia de Pearson y la distancia de identidad de similitud para garantizar la singularidad de cada perfil de fuente. En general, las especies más dominantes en los perfiles fueron el carbono orgánico, el carbono elemental y el azufre elemental, mientras que las menos abundantes fueron los metales de transición. Los perfiles de operaciones de cocción de alimentos exhibieron las proporciones más altas de carbono orgánico a carbono elemental, que fueron de 7 a 40 veces más altas que las de los perfiles de quema de biomasa y emisiones de vehículos. El perfil de construcción urbana estuvo compuesto principalmente por elementos de origen de la corteza terrestre, mientras que el perfil del área suburbana exhibió una mezcla de compuestos antrópicos. Los perfiles de emisión difieren entre sí, según lo determinado por pruebas de similitud para cada par de perfiles de fuentes químicas. Estos perfiles podrían usarse para implementar modelos de receptores en sitios urbanos con características similares.

\section{INTRODUCTION}

Around the world, $\mathrm{PM}_{2.5}$ (fine particles with aerodynamic diameters less than $2.5 \mu \mathrm{m}$ ) are significant pollutants that affect air quality in urban areas (WHO 2016). Moreover, high concentrations of $\mathrm{PM}_{2.5}$ in ambient air are associated with visibility, economic, and human health impacts (Pope et al. 2011, Grahame et al. 2014, Yang et al., 2019). Evidence suggests that considerable exposure to $\mathrm{PM}_{2.5}$ increases the risk of suffering from cardiovascular and respiratory diseases (Anake et al. 2020). Recently, the black carbon (BC) content of $\mathrm{PM}_{2.5}$ was significantly associated with cardiovascular disease mortality (Kirrane et al. 2019). However, very few comparable data are available for other locations around the world (Hopke et al. 2020).

There is continuous interest in accurately representing the chemical composition of $\mathrm{PM}_{2.5}$ because such knowledge will enable possible emission sources to be identified. This is important because different regions have varied chemical compositions; in addition, such chemical compositions are associated with $\mathrm{PM}_{2.5}$ toxicities (Anake et al. 2020). Chemical markers that are commonly used to trace source contributions include trace elements, soluble inorganic compounds, elemental carbon (EC), and compounds found in the organic carbon (OC) fraction of aerosols ( $\mathrm{Li}$ et al. 2010). The specific composition of emission from different sources, such as vehicle exhaust, cooking operations, industries, biomass burning, vegetative detritus, and fugitive dusts should be determined to integrate a chemical source profile and accurately estimate the relative contribution of major emission sources to ambient $\mathrm{PM}_{2.5}$ concentrations (Pernigotti et al. 2016, Singh et al. 2017, Liu et al. 2018a, Miller et al. 2019, Hopke et al. 2020). These profiles can be used for different applications:
1) performing receptor models based on chemical profiles, such as chemical mass balance (CMB) models; 2) establishing a better speciated emissions inventory that could serve as input data to dispersion models; 3) interpreting the output of receptor models based exclusively on speciated ambient samples (such as positive matrix factorization [PMF]). CMB is a powerful and widely used receptor model that estimates the relative contribution of an emission source to ambient $\mathrm{PM}_{2.5}$ concentrations (USEPA 2004, Karagulian et al. 2015, Hopke et al. 2020). However, CMB's results are often limited because the source profiles used might be site-specific; given that emission sources are quite different between sites, they cannot be easily generalized. Thus, the development and availability of source profiles relevant for different study areas are highly recommended (Xie et al. 2012, Belis et al. 2015, Karagulian et al. 2015). In spite of this limitation, several studies around the world used profiles from other sites to conduct source apportionment studies in order to identify tendencies in source contributions (Mohr et al. 2009, Karagulian et al. 2015, Mancilla et al. 2016, Kalaiarasan et al. 2018, Rehman et al. 2020).

Therefore, in the international context, the data of chemical source profiles must be increased. In Mexico, public resources are allocated to determine the causes of air quality deterioration using reference stations to monitor criteria pollutants in 83 cities (INECC 2019a). However, few studies have been conducted to chemically characterize fine particles in Mexican cities such as San Luis Potosí (INECC 2018a), Mexico (INECC 2019b) and Juárez (INECC 2018b). The Monterrey Metropolitan Area (MMA), which is the third most populated urban center in Mexico, hast to deal with air quality problems due to high concentrations of ambient $\mathrm{PM}_{2.5}$ (INECC 2019a). The chemical composition of ambient $\mathrm{PM}_{2.5}$ 
in this urban area has been widely studied (BadilloCastañeda et al. 2015, Blanco-Jiménez et al. 2015, Martínez-Cinco et al. 2016, Mancilla et al. 2018). Moreover, source apportionment studies using data available for other locations around the world were conducted (Mancilla et al. 2016, Martínez-Cinco et al. 2016). These studies show that vehicle exhaust, cooking operations, and industries are major contributors to ambient $\mathrm{PM}_{2.5}$. The registered vehicle fleet of the MMA consists of 1.7 million passenger cars, 10000 buses, 468000 heavy trucks and 84000 motorcycles (INEGI 2020). In relation to cooking operations, the average consumption of meat in the MMA is $29 \mathrm{~kg} /$ person, which is $71 \%$ more than the national average. The culinary industry of the region is composed of more than 16000 restaurants (INEGI 2015). Finally, the industrial activity in the MMA involves 135000 economical units and is dominated by manufacturing $(23 \%)$, stores $(17 \%)$, construction (9\%), transport (9\%), and others (19\%) (INEGI 2017).

This work provides, for the first time, data of chemical source profiles based on the composition of trace elements, EC and OC for diesel-fueled vehicle exhausts, meat cooking operations, oil refinery and manufacturing industries, open-waste burning, and construction dust in the MMA. Moreover, for the second time, this study presents a chemical source profile for gasoline-fueled vehicle exhausts. These profiles provide necessary region-specific source profile data which are typically not measured in developing countries. Because these profiles were obtained based on a near-source measurement approach, correction by possible paved-road dust resuspension interference was applied to reflect a better composition of emissions and reduce errors in resulting source apportionment studies (Hopke et al. 2020). This is of particular relevance, given that the MMA is located in a semi-arid region where dry conditions foster the presence of dust in the ambient air. In addition, statistical tests were performed to establish a degree of similarity of the obtained profiles, thus ensuring source representativeness. The obtained source profiles can be used to conduct source apportionment studies in the MMA or other locations with similar emission sources.

\section{MATERIALS AND METHODS}

\section{Sources and sampling locations}

In the current investigation, the potential major source types that contribute to $\mathrm{PM}_{2.5}$ concentrations in the MMA were identified from previous studies (Mancilla et al. 2016, Martínez-Cinco et al. 2016) and official emission inventories (SEDESU 2016). Source samples were collected from 12 locations in the MMA (Mexico) from June 19, 2014 to July 22, 2014. The collected samples represent (1) residential and commercial meat cooking operations from natural gas and charcoal; (2) motor vehicle exhausts from gasoline- and diesel-fueled vehicles, including passenger cars and urban and freight transport; (3) open-waste burning; (4) oil refinery and manufacturing industries, and (5) urban background profiles including suburban area and urban construction sites.

All the samples were collected following the ground-based source-dominated method for source profile characterization (Chow et al. 2004, Zhao et al. 2019). Two filter-based instruments were used at the same time to collect the samples from each source emission. A low-volume sampler (MiniVol, Airmetrics) was used to collect samples on $47 \mathrm{~mm}$ Teflon filters with pore size of $0.2 \mu \mathrm{m}$ (Whatman PTFE membrane circles, TE36) at an average flow rate of $0.34 \mathrm{~m}^{3} / \mathrm{h}(\sim 5.7 \mathrm{Ll} / \mathrm{min})$. The oother equipment was a high-volume sampler (TE-6070-2.5, Tisch Environmental) used to collect samples on $0.20 \times 0.25 \mathrm{~m}$ pre-fired micro-quartz filters with pore size $2.2 \mu \mathrm{m}$ (Whatman QM-A) at an average flow rate of $69 \mathrm{~m}^{3} / \mathrm{h}$. The two samplers were calibrated before starting each sampling test by using certificated orifice calibrators (NIST traceable standard) MNF-1236 and TE-5040 for the MiniVol and Hi-Vol samplers, respectively. These calibrations were conducted to estimate a more precise flow rate sampling for each sampler. Quartz filters were collected by using Hi-Vol samplers instead of a MiniVol sampler due to further chemical analysis that will require higher amounts $(>400 \mu \mathrm{g})$ of organic carbon as a complement study of this work. The sampling locations, descriptions and times are shown in table I and illustrated in figure 1; preliminary sampling tests were conducted to define the most adequate sampling times for each chemical source profile. The same number of samples and sampling time per filter type were collected for each emission source profile. The average sampling volume can be calculated using the flow rates for each sampler and the average sampling time; for the Teflon filters these volumes range from 0.3-5.7 $\mathrm{m}^{3}$ while for Quartz filters they range from $78-1162 \mathrm{~m}^{3}$ with a correlation $(r)$ between volumes of 0.88 .

\section{Sampling sites description}

Motor vehicle exhaust samples were collected for gasoline- and diesel-fueled vehicles from a road 
TABLE I. SUMMARY OF SAMPLING SCHEMES FOR THE DIFFERENT EMISSION SOURCES.

\begin{tabular}{|c|c|c|c|c|}
\hline Source & Profile (samples used) & Code & $\begin{array}{l}\text { Number of } \\
\text { samples per } \\
\text { filter type }\end{array}$ & $\begin{array}{c}\text { Average } \\
\text { sampling time } \\
\text { (h) }\end{array}$ \\
\hline \multirow{3}{*}{$\begin{array}{l}\text { Meat cooking } \\
\text { operations }\end{array}$} & $\begin{array}{l}\text { Restaurant charbroiled and grilled meat: late afternoon samples. } \\
\left(25^{\circ} 39^{\prime} 18.9^{\prime} \mathrm{N}, 100^{\circ} 17^{\prime} 29.2^{\prime} \mathrm{W}\right)\end{array}$ & CAR & 2 & 3.99 \\
\hline & $\begin{array}{l}\text { Residential charbroiled meat: late afternoon samples including start and } \\
\text { end of burn and cooking process. }\left(25^{\circ} 39^{\prime} 00.5^{\prime \prime} \mathrm{N}, 100^{\circ} 17^{\prime} 05.5^{\prime \prime} \mathrm{W}\right)\end{array}$ & $\mathrm{CAF}$ & 2 & 2.90 \\
\hline & $\begin{array}{l}\text { Supermarket charbroiled meat service. Afternoon samples including start } \\
\text { and end of burn and cooking process. }\left(25^{\circ} 38^{\prime} 21.7^{\prime \prime} \mathrm{N}, 100^{\circ} 17^{\prime} 00.6^{\prime \prime} \mathrm{W}\right)\end{array}$ & CAS & 2 & 2.28 \\
\hline \multirow{3}{*}{$\begin{array}{l}\text { Vehicle } \\
\text { exhausts }\end{array}$} & $\begin{array}{l}\text { Gasoline-fueled vehicles: heavy traffic in a bore tunnel with a }+3.5 \% \\
\text { slope (Loma Larga Tunnel). }\left(25^{\circ} 39^{\prime} 30.25^{\prime \prime} \mathrm{N}, 100^{\circ} 20^{\prime} 11.85^{\prime \prime} \mathrm{W}\right)\end{array}$ & TLL & 3 & 3.60 \\
\hline & $\begin{array}{l}\text { Urban Transport: ground-based samples from intersection of Av. Juárez } \\
\text { and Arteaga Street. }\left(25^{\circ} 40^{\prime} 59.2^{\prime \prime N}, 100^{\circ} 18^{\prime} 48.6^{\prime} \mathrm{W}\right)\end{array}$ & $\mathrm{TP}$ & 3 & 3.43 \\
\hline & $\begin{array}{l}\text { Freight transport: ground-based samples from intersection of Av. Félix U. } \\
\text { Gómez and Av. Ciudad Los Ángeles. }\left(25^{\circ} 42^{\prime} 28.7^{\prime} \mathrm{N}, 100^{\circ} 16^{\prime} 55.9^{\prime} \mathrm{W}\right)\end{array}$ & $\mathrm{CC}$ & 3 & 2.62 \\
\hline \multirow{2}{*}{ Industry } & $\begin{array}{l}\text { Oil refinery: daytime samples in a hot spot near to the refinery. } \\
\left(25^{\circ} 36^{\prime} 10^{\prime \prime} \mathrm{N}, 99^{\circ} 59^{\prime} 19.7^{\prime} \mathrm{W}\right)\end{array}$ & PMX & 2 & 12.94 \\
\hline & $\begin{array}{l}\text { Manufacturing industry: daytime samples in a hot spot near to an } \\
\text { industrial park. }\left(25^{\circ} 39^{\prime} 30.25^{\prime \prime} \mathrm{N}, 100^{\circ} 20^{\prime} 11.85^{\prime \prime} \mathrm{W}\right)\end{array}$ & PSN & 4 & 8.00 \\
\hline \multirow[t]{2}{*}{$\begin{array}{l}\text { Biomass and } \\
\text { trash burning }\end{array}$} & $\begin{array}{l}\text { Open-waste burning: field burn samples including start and end burn, } \\
\text { active burn and heavy smoke. }\left(25^{\circ} 41^{\prime} 24.1^{\prime \prime} \mathrm{N}, 100^{\circ} 10^{\prime} 00.1^{\prime \prime} \mathrm{W}\right)\end{array}$ & QB & 2 & 0.89 \\
\hline & $\begin{array}{l}\text { Suburban area in daytime: daytime samples during spring-summer time. } \\
\left(25^{\circ} 29^{\prime} 34.1^{\prime \prime} \mathrm{N}, 100^{\circ} 10^{\prime} 52.8^{\prime} \mathrm{W}\right)\end{array}$ & RTD & 3 & 6.80 \\
\hline \multirow[t]{2}{*}{$\begin{array}{l}\text { Urban } \\
\text { background }\end{array}$} & $\begin{array}{l}\text { Suburban area in nighttime: nighttime samples during spring-summer } \\
\text { time. }\left(25^{\circ} 29^{\prime} 34.1^{\prime \prime N}, 100^{\circ} 10^{\prime} 52.8^{\prime \prime} \mathrm{W}\right)\end{array}$ & RTN & 2 & 15.24 \\
\hline & $\begin{array}{l}\text { Urban construction site: line } 3 \text { of the city subway construction site on the } \\
\text { Av. Félix U. Gómez. }\left(25^{\circ} 41^{\prime} 24.1^{\prime \prime} \mathrm{N}, 100^{\circ} 17^{\prime} 47.5^{\prime \prime} \mathrm{W}\right)\end{array}$ & $\mathrm{RP}$ & 2 & 2.21 \\
\hline
\end{tabular}

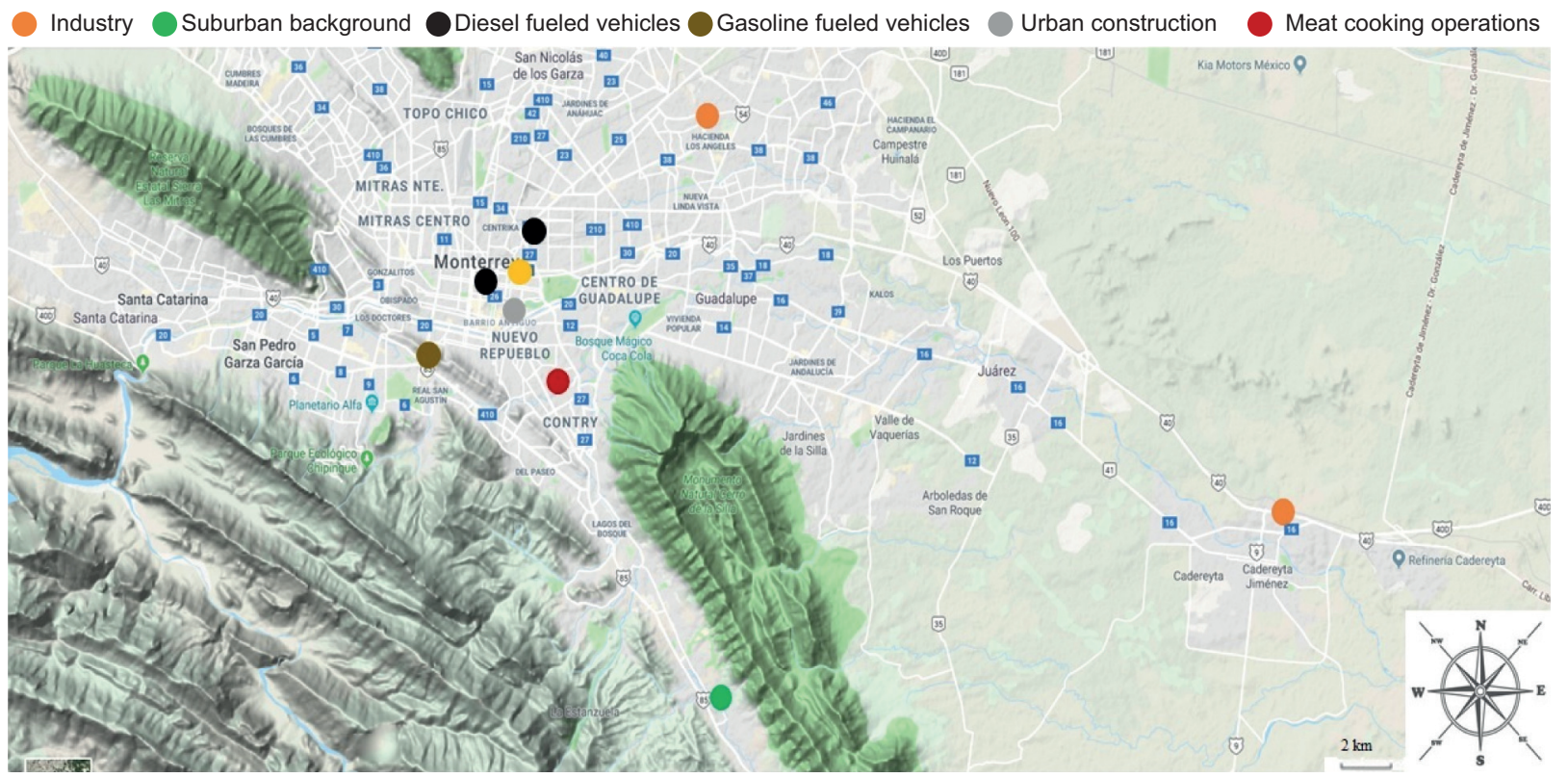

Fig. 1. Locations of sampling sites for source profiles within the MMA. 
tunnel and through side-road sampling, respectively. In all cases, the samplers were placed on a sidewalk within $2 \mathrm{~m}$ of the traffic lane, with the sampling inlet placed at $1.5 \mathrm{~m}$ above ground level. For the case of the road tunnel, general guidelines from a previous study in the same tunnel were followed (Araizaga et al. 2013). Three samples were collected in a two-bore urban tunnel (532 m long) in which the traffic is composed of $98 \%$ gasoline-fueled vehicles, including motorcycles and passenger cars (Araizaga et al. 2013). The samplers were located 200 $\mathrm{m}$ downstream from the inlet of the bore; the traffic on the selected bore is subject to a $3.5 \%$ positive slope. The vehicle exhausts for diesel trucks were divided into urban (public and private buses) and freight transport (at least four-axle single units and trailers). Information about the streets in the MMA with high urban and freight transport traffic was provided by the Secretaría de Seguridad Pública y Viabilidad de Monterrey (Monterrey Department of Public Safety and Roads). Based on this information, two locations were selected for sampling these source emissions. Samples were collected from these public road-side locations during the hours in which the fleet of gasoline-powered vehicles was low, which was determined by previously conducted vehicle count tests in these avenues. During the tests, the average vehicular capacities through each avenue were 400 buses and 200 freight trucks per hour for the urban and freight transport avenues, respectively.

Meat cooking emissions were collected based on the most frequent forms of cooking operations in the MMA. These samples included emissions from restaurants that use natural gas for combustion purposes and seed oils for heating (hot plate) and cooking food, supermarket charbroiled meat services, and residential charbroiled meat activities. In all cases, sampling was conducted under real conditions, which implied uncontrolled, non-conducted, open operations. In particular, the residential cooking test was comprised by a specific combination of meat types and other food complements (e.g., sausage, onions, cheese) using an outdoor charbroiling system. All tests involved the cooking of meat from beef, pork, sausage, and other typical food dishes associated with traditional charbroiled cooking operations in the MMA. The sampling equipment was positioned at $5 \mathrm{~m}$ downwind from each source; in the particular case of restaurant emissions, this implied positioning the sampling equipment in open, public spaces in the surroundings of the cooking operations.

The biomass and trash burning profile was obtained by ground-based source-dominated sampling in plumes of real open-waste burning emissions. The waste burning consisted of wood, grass, leaves, plastics, cardboard, paper, textiles, and household items. Two samples were collected at $2 \mathrm{~m}$ downwind from the open fire, where the plume directly impacted the sampler. This procedure was conducted in the suburbs of the MMA, where these burnings often occur. The site was located from an opportunity chase process: drive arounds and fire occurrence identification in open spaces.

The urban background profile was obtained by sampling in an open space $\left(\sim 60000 \mathrm{~m}^{2}\right)$, property of the Tecnológico de Monterrey, located in the suburban area of the MMA at $\sim 30 \mathrm{~km}$ southeast from the downtown area. This type-of-villa space is far from the urban area, thus allowing the isolation of biogenic emissions. This site is a natural ecosystem for recreational purposes (uninhabited) and consists of shrubs, grass, and trees. Several activities, such as cooking operations and swimming, are frequently carried out in this site. Sampling was conducted during periods in which these activities were not occurring in order to minimize their influence on the profile. The photochemical oxidation of particles produced over natural areas leads to secondary organic aerosol (SOA) formation (Xu et al. 2020). Three samples were collected for daytime and two for nighttime to distinguish SOA formation. The samplers were placed on a small building's rooftop, with the sampling inlet at $4.5 \mathrm{~m}$ above the ground.

Industrial profiles were obtained for oil refinery and manufacturing industry emissions. Sampling locations were set based on the locations of reference stations deployed to monitor these ambient hot spots. For the oil refinery, two samples were collected from a sampling site located at $3 \mathrm{~km}$ downwind from the source, positioned in a public open space. This oil refinery is composed of more than 30 facilities that process around 110 thousand barrels of petroleum per day to produce mainly gasoline and diesel fuels. For the industrial emissions, the selected site was an industrial park that houses several manufacturing companies in the field of automotive assembly, electrical appliances, cosmetics, and engineering products. Unlike the case of the oil refinery, four samples were collected from a sampling site located within $1 \mathrm{~km}$ downwind from these industrial sources, also positioned in a public open space.

The urban construction profile was obtained by positioning the samplers nearby an urban construction area. This area is influenced by particles coming from pave roads and the construction operations of a new subway line for local transportation. Significant 
resuspension of particles occurred due to construction activities that required the use of materials and machinery, such as concrete and off-road vehicles, respectively.

\section{Chemical characterization}

The Teflon filters were analyzed for mass by gravimetry using a Sartorius ME5 microbalance $(1 \mathrm{mg}$ readability) in a weighing chamber with controlled temperature and relative humidity to obtain the total collected particulate matter. The allowable weighing temperature was a 24 -h average between 20 and $23^{\circ} \mathrm{C}$ (standard deviation less than $2^{\circ} \mathrm{C}$ ), and the 24 -h mean relative humidity was maintained between 30 and $40 \%$ (standard deviation less than $5 \%$ ). Then, the same filters were analyzed for 38 trace elements ( $\mathrm{Na}$ to $\mathrm{Pb}$ ) by X-ray fluorescence (XRF) and using a KEVES EDX-771 X-ray spectrometer following protocol six of the non-destructive analytical method (IO-3.3) approved by the US-EPA (EPA/625/R-96/010a). In this method, a filter is bombarded with X-ray energy; then, the excitement of electrons release energy that can be measured. Each element has a characteristic energy discharge which is measured to determine the quantity of each element (Method IO-3.3).

The micro-quartz filters were analyzed for OC and EC by thermal-optical transmittance (TOT) using a Sunset Laboratory thermo-optical carbon analyzer (Model 4L); samples were analyzed using the normal parameters for the NIOSH 5040 method with modified parameters that increased and lengthened the heating steps in order to keep the instrument from going over scale. A $1 \mathrm{~cm} \times 1.5 \mathrm{~m}$ standard punch $\left(1.5 \mathrm{~cm}^{2}\right)$ was extracted from a loaded quartz microfiber filter and placed in an oven using a quartz boat. The transmittance of a diode laser light through the filter was monitored during the analysis. The oven was initially purged with He. OC was then analyzed over varying time steps between $45 \mathrm{~s}$ and $300 \mathrm{~s}$ during the $\mathrm{OC}$ evolution at $310^{\circ} \mathrm{C}$, $475^{\circ} \mathrm{C}, 615^{\circ} \mathrm{C}$, and $870{ }^{\circ} \mathrm{C}$ in an inert atmosphere (pure $\mathrm{He}$ ). The heating desorbed $\mathrm{OC}$ thermally. The evolved $\mathrm{OC}$ was catalytically oxidized to $\mathrm{CO}_{2}$ in a manganese dioxide $\left(\mathrm{MnO}_{2}\right)$ oxidizing oven; subsequently, the $\mathrm{CO}_{2}$ was swept out of the oxidizing oven with the He stream and reduced to $\mathrm{CH}_{4}$ in a (Ni/firebrick) methanator and quantified as $\mathrm{CH}_{4}$ by a flame ionization detector (FID). The EC analysis was conducted using temperature profiles of $550^{\circ} \mathrm{C}$, $625^{\circ} \mathrm{C}, 700^{\circ} \mathrm{C}, 775^{\circ} \mathrm{C}$, and $850^{\circ} \mathrm{C}$ with a withhold time of $45 \mathrm{~s}$ and a final holding time of $120 \mathrm{~s}$ at $870^{\circ} \mathrm{C}$ in an oxidizing atmosphere $\left(\mathrm{He}: \mathrm{O}_{2} 90: 10 \mathrm{v} / \mathrm{v}\right)$. EC was oxidized from the filter into the oxidation oven, converted into $\mathrm{CO}_{2}$, reduced to $\mathrm{CH}_{4}$, and detected by FID as $\mathrm{CH}_{4}$. During this stage, a pyrolysis correction was made. A split point should be defined for OC and EC to quantify these components. The split point is defined as the point at which the light transmittance of the sample returns to the initial value. The carbon that evolved before or after the split point was considered OC or EC, respectively (Birch and Cary 1996). All laboratory analyses were conducted by Chester LabNet (Tigard, OR).

\section{Correction of chemical source profile by dust resuspension}

The source particle mass concentrations of trace metals and carbonaceous species can be impacted by dust resuspension given the ground-based sourcedominated method utilized in this study. Hence, a correction for each profile sample based on mass percent was implemented as per equation 1 .

$\left(m_{i, k}\right)_{\text {corrected }}=\left(m_{i, k}\right)_{\text {source }}-\left(\frac{m_{i}}{m_{s i}}\right)_{\text {dust profile }} \times m_{s i, k}$

where $\left(m_{\mathrm{i}, \mathrm{k}}\right)_{\text {corrected }}$ is the corrected mass percent of element $i$ in profile $k,\left(m_{\mathrm{i}, \mathrm{k}}\right)_{\text {source }}$ is the source mass percent estimated from each sample of element $i$ in profile $k,\left(m_{\mathrm{i}} / m_{\mathrm{si}}\right)_{\text {dust profile }}$ is the ratio of the mass percentages of element $i$ to the concentration of silicon in the dust profile selected as the reference, and $m_{\mathrm{si}, \mathrm{k}}$, is the mass percent of the silicon element in profile $k$. The dust profile used as the reference was the profile developed for a tunnel study in the MMA used in Mancilla et al. (2016).

In addition, the uncertainty corresponding to each $\left(C_{\mathrm{i}, \mathrm{k}}\right)_{\text {corrected }}$ was identified. In cases where measurements were combined to form a "pooled" profile, an error propagation technique was followed to estimate the final uncertainties. The uncertainties of the individual profiles were considered independent and random in such a way that follows the sum in the quadrature technique (Taylor 1997). The estimated final uncertainties were calculated by adding the squares of each measured value and obtaining the square root.

\section{Carbonaceous indicator (OC/EC)}

In addition, a useful indicator for primary emission sources is the OC/EC ratio. Values between 1 and 3 for this ratio can be an indicator of primary emissions that come from fossil fuel combustion (Chow et al. 2010, Yan et al. 2019). However, high values of $\mathrm{OC} / \mathrm{EC}$ ratios $(>3)$ can also be an indicator 
of contributions from other primary sources (Cabada et al. 2004, Chow et al. 2010, Hoyle et al. 2011). For example, some studies have reported high OC/ EC ratios of 17 to 40 for wood combustion (Feng et al. 2009), approximately 3 to 7 for general biomass burning (Tao et al. 2013), and 2 to 54 for cooking operations (Wang et al. 2015a). Conversely, high values of OC/EC ratios ( $>3$ ) in ambient air samples can also be an indicator of SOA due to the photochemical oxidation of OC in the atmosphere (Hayes et al. 2013, Mancilla et al. 2015, Xu et al. 2020).

\section{Similarity tests between chemical source profiles}

A tool is needed to assess the homogeneity of chemical source profiles (Karagulian et al. 2015). The similarities between sources were tested with both the Pearson distance (PD) and the similarity identity distance (SID) in accordance with Belis et al. (2015). PD is equal to $1-r^{2}$, where $r^{2}$ is the Pearson coefficient, and SID is defined by equation 2 (Weber et al. 2019):

$S I D=\frac{\sqrt{2}}{m} \sum_{j=1}^{m} \frac{\left|x_{j}-y_{j}\right|}{x_{j}+y_{j}}$

where $x_{\mathrm{j}}$ and $y_{\mathrm{j}}$ are the relative masses of species $j$ to the $\mathrm{PM}_{2.5}$ of two different source profiles and $m$ is the number of common species between $x$ and $y$. These two metrics (PD and SID) aim to compare two profiles based on their common chemical relative mass composition. PD is highly sensitive to variations in the major components of $\mathrm{PM}_{2.5}$, while SID is evenly sensitive to all components (Weber et al. 2019). PD $<0.4$ and SID $<0.8$ are acceptable criteria for profile similarity (Weber et al. 2019).

\section{RESULTS AND DISCUSSION}

\section{$\mathbf{P M}_{2.5}$ composition for individual source profiles}

Based on the chemical characterization of each source profile, the main chemical species and diagnostic ratios were identified and estimated, respectively, to assess the uniqueness of the profiles. The main chemical species for each profile are summarized in table II, and the average source profiles (mass percent) are shown in figures 2-5. The average source profiles were calculated by averaging the samples collected for each emission source. In addition, the $\mathrm{Si}$ was not reported for each profile due to correction by dust resuspension; the Si contribution before the correction ranged from $0.03 \%$ to $9.07 \%$ while for the dust profile used for the correction was $25.7 \%$. Finally, the developed source profiles in this study are representative for spring-summer sampling periods.

Figure 2 compares the average abundances of the profiles for gasoline- and diesel-fueled vehicles. The three gasoline-fueled vehicle profiles (TLL) are dominated by OC (6-31 \%), EC (2-10\%), and S (3-8 \%). Other appreciable elements (0.01-1.0\%) in the profiles from this study were $\mathrm{Na}, \mathrm{Mg}, \mathrm{Al}, \mathrm{Cl}, \mathrm{Fe}$, $\mathrm{Cu}, \mathrm{Sb}, \mathrm{Ti}$, and $\mathrm{Zn}$. This dominance was different in Mexico City, where OC, EC, $\mathrm{Br}$ and $\mathrm{Pb}$ are the key components of vehicle emissions (INECC 2019b). Unlike in Hao et al. (2019), Hg was not detected in the gasoline profiles; in addition, the average abundances of $\mathrm{Al}, \mathrm{Pb}, \mathrm{OC}$, and $\mathrm{EC}$ were 55-85, 70$95,40-70$, and 5-30\% lower than those reported in Kang et al. (2010), Zhang et al. (2015) and Hao et al. (2019), respectively.

Both diesel-fueled vehicle profiles (freight transport $[\mathrm{CC}]$ and urban transport profiles [TP]) were dominated by OC (CC: 17-18 \%; TP: $8-24 \%$ ), EC (CC: $11-12 \%$; TP: $3-24 \%$ ) and S (CC: $2.2-3.6 \%$; TP: $2.0-3.7 \%)$. Other noticeable trace elements (0.1-1.0\%) were $\mathrm{Sn}, \mathrm{Ag}, \mathrm{Na}, \mathrm{Cl}, \mathrm{Fe}$, and Al. The average abundance of $\mathrm{Al}$ was 70 and $97 \%$ lower than those reported by Liu et al. (2018b) and Pulong et al. (2017), respectively. The average abundance of Fe was 2, 4, and 16 times higher than those reported by Hao et al. (2019), Zhang et al. (2016), and Cui et al. (2017), respectively, whereas it was $80 \%$ lower than that reported by Pulong et al. (2017). Unlike in the urban transport profile, Ag was not detected in other studies, and the average abundance of EC was $35-40 \%$ lower than those reported for other diesel profiles by Kang et al. (2010), Cui et al. (2017), Liu et al. (2018b), and Hao et al. (2019). In the course of this study the quality of gasoline and diesel followed Euro IV standards, however, differences in the abundances of some species can also be associated with vehicle maintenance and age (INECC 2019c).

Figure 3 compares the average abundances of the profiles for meat cooking operations. These profiles were divided into three types: residential charbroiled meat (CAF), restaurant charbroiled meat (CAR), and supermarket charbroiled meat service (CAS). Firstly, for the residential charbroiled meat, the profiles were dominated by OC (26-86\%), $\mathrm{Cl}(2-5 \%), \mathrm{EC}(0.4-4 \%)$, $\mathrm{K}(3 \%), \mathrm{Na}(0.5 \%)$, and $\mathrm{S}(0.3-0.4 \%)$. Secondly, for the restaurant profiles, the most abundant species were OC (2-18\%), Cl (4-17\%), K (8-16\%), S (2-3\%), $\mathrm{Na}(1 \%)$, and EC (0.1-0.3\%). Finally, the supermarket profiles were dominated by OC (73-99\%), 
TABLE II. SUMMARY OF KEY MARKERS AND OC/EC RATIOS FOR THE DIFFERENT SOURCE PROFILES.

\begin{tabular}{|c|c|c|c|c|}
\hline \multirow[t]{2}{*}{ Source Profile } & \multicolumn{4}{|c|}{ Chemical abundances in mass percent } \\
\hline & $<0.1 \%$ & $0.1-1.0 \%$ & $1.0-10 \%$ & $>10 \%$ \\
\hline Residential charbroiled (CAF) & $\mathrm{Zn}, \mathrm{Pb}, \mathrm{Ba}, \mathrm{Cu}, \mathrm{V}, \mathrm{Mn}, \mathrm{Co}, \mathrm{Cr}$ & $\mathrm{Na}, \mathrm{S}$ & $\mathrm{Cl}, \mathrm{K}, \mathrm{EC}$ & $\mathrm{OC}$ \\
\hline Restaurant charbroiled (CAR) & $\mathrm{Zn}, \mathrm{Mg}, \mathrm{Cu}, \mathrm{V}, \mathrm{Mn}, \mathrm{Cr}, \mathrm{Ni}$ & $\mathrm{EC}$ & $\mathrm{Na}, \mathrm{S}, \mathrm{Cl}, \mathrm{K}, \mathrm{Ca}$ & $\mathrm{OC}$ \\
\hline $\begin{array}{l}\text { Supermarket charbroiled service } \\
\text { (CAS) }\end{array}$ & $\mathrm{Zn}, \mathrm{Pb}, \mathrm{Mg}, \mathrm{Cu}, \mathrm{V}, \mathrm{Co}, \mathrm{Cr}, \mathrm{Ni}$ & $\mathrm{Al}, \mathrm{Sn}$ & $\mathrm{Na}, \mathrm{S}, \mathrm{Cl}, \mathrm{K}, \mathrm{EC}$ & $\mathrm{OC}$ \\
\hline Gasoline-fueled vehicles (TLL) & $\begin{array}{c}\mathrm{P}, \mathrm{Ti}, \mathrm{V}, \mathrm{Cr}, \mathrm{Mn}, \mathrm{Cu}, \mathrm{Zn}, \mathrm{Sb} \\
\mathrm{Sr}, \mathrm{Pb}\end{array}$ & $\mathrm{Na}, \mathrm{Mg}, \mathrm{Al}, \mathrm{Cl}, \mathrm{Fe}, \mathrm{Zn}$ & $\mathrm{S}, \mathrm{EC}$ & $\mathrm{OC}$ \\
\hline Urban transport (TP) & $\begin{array}{l}\text { V, Cr, Mn, Zn, Se, As, Sr, Zr, } \\
\text { Mo, Sn, Sb, Pb, Ti }\end{array}$ & $\mathrm{Al}, \mathrm{Cl}, \mathrm{Fe}, \mathrm{Ag}$ & $\mathrm{Na}, \mathrm{S}$ & $\mathrm{OC}, \mathrm{EC}$ \\
\hline Freight transport (CC) & $\begin{array}{c}\text { V, Zn, Cr, Mn, Se, As, Sr, Zr, } \\
\text { Mo, Hg, Hg }\end{array}$ & $\mathrm{Na}, \mathrm{Mg}, \mathrm{Al}, \mathrm{Cl}, \mathrm{Fe}, \mathrm{Sn}$ & $\mathrm{S}$ & $\mathrm{OC}, \mathrm{EC}$ \\
\hline Oil refinery (PMX) & $\mathrm{Cr}, \mathrm{Mn}, \mathrm{Cu}, \mathrm{Zr}, \mathrm{Cd}, \mathrm{Hg}$ & $\mathrm{Mg}, \mathrm{Al}, \mathrm{Cl}, \mathrm{K}, \mathrm{Ti}, \mathrm{Fe}, \mathrm{Sb}$ & $\mathrm{Na}, \mathrm{S}, \mathrm{EC}$ & $\mathrm{OC}$ \\
\hline Manufacturing industry (PSN) & $\begin{array}{l}\mathrm{P}, \mathrm{V}, \mathrm{Mn}, \mathrm{Cu}, \mathrm{Zn}, \mathrm{Ge}, \mathrm{As}, \mathrm{Se} \\
\mathrm{Br}, \mathrm{Sr}, \mathrm{Zr}, \mathrm{Mo}, \mathrm{Pd}, \mathrm{In}, \mathrm{Sn}, \mathrm{Pb}\end{array}$ & $\begin{array}{c}\mathrm{Na}, \mathrm{Mg}, \mathrm{Al}, \mathrm{Cl}, \mathrm{K}, \mathrm{Cr}, \mathrm{Fe} \\
\mathrm{Pb}\end{array}$ & $\mathrm{EC}$ & $\mathrm{S}, \mathrm{OC}$ \\
\hline Biomass and trash burning $(\mathrm{QB})$ & $\begin{array}{c}\mathrm{Al}, \mathrm{Ti}, \mathrm{Cr}, \mathrm{Mn}, \mathrm{Fe}, \mathrm{Sr}, \mathrm{Cd}, \mathrm{In} \\
\mathrm{Ba}, \mathrm{Hg}, \mathrm{Pb}\end{array}$ & $\mathrm{Na}, \mathrm{Mg}, \mathrm{S}, \mathrm{Zn}, \mathrm{Br}, \mathrm{Sn}$ & $\mathrm{Cl}, \mathrm{K}$ & $\mathrm{OC}, \mathrm{EC}$ \\
\hline Suburban area (RT) & $\begin{array}{c}\mathrm{Ti}, \mathrm{Cr}, \mathrm{Mn}, \mathrm{Cu}, \mathrm{Zn}, \mathrm{Mo}, \mathrm{In}, \\
\mathrm{Hg}, \mathrm{Pb}\end{array}$ & $\mathrm{Na}, \mathrm{Mg}, \mathrm{Al}, \mathrm{Cl}, \mathrm{K}$ & $\mathrm{S}, \mathrm{EC}$ & $\mathrm{OC}$ \\
\hline Urban construction site (RP) & $\begin{array}{c}\mathrm{P}, \mathrm{Cr}, \mathrm{As}, \mathrm{Zr}, \mathrm{Mo}, \mathrm{Sn}, \mathrm{Hg}, \mathrm{Pb} \\
\mathrm{Ni}, \mathrm{Mn}\end{array}$ & $\mathrm{Mg}, \mathrm{Cl}, \mathrm{K}, \mathrm{Ti}, \mathrm{Zn}, \mathrm{Sb}, \mathrm{Pb}$ & $\mathrm{Ca}, \mathrm{S}, \mathrm{EC}$ & $\mathrm{OC}$ \\
\hline
\end{tabular}

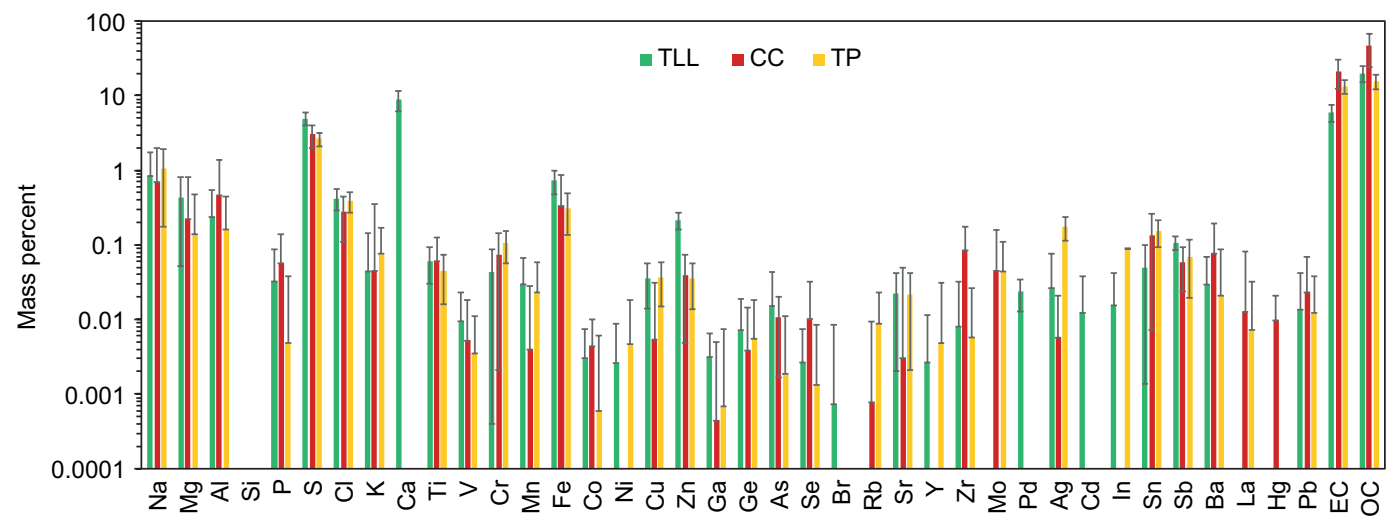

Fig. 2. Profiles for vehicle eemissions (see Table I for definitions of acronyms).

Cl (1.8-4.2\%), K (1.9-4.8\%), S (1-2\%), Na (1 \%), and EC (1.4-4.3\%). S could be one of the impurities in charcoal and can be released to the atmosphere in the form of sulfur dioxide $\left(\mathrm{SO}_{2}\right)$ (Susaya et al. 2010, Vicente et al. 2018). In addition, $\mathrm{S}$ is a major element emitted from cooking operations (Zhao et al. 2019); its values can range from 0.14 to $4.2 \%$, depending on the kind of biomass being burned (Sun et al. 2019a). Cr contributions typically come from stainless steel utensils (Zhao et al. 2019), while Mn and $\mathrm{Pb}$ could be emitted from cooking oil (Wang et al. 2011). Unlike in Zhao et al. (2019), the Ca in the current study was not representative $(<0.1 \%)$. The $\mathrm{Al}, \mathrm{Mg}$, and $\mathrm{Fe}$ abundances $(\mathrm{Al}, \mathrm{Mg}$, and $\mathrm{Fe}<0.1 \%$; $\mathrm{Na}<1.0 \%$ ) were lower than those from Wang et al. (2015a) (Al: 0.5 \%; Mg: 0.6\%; Fe: $1.0 \%$; Na: $1.4 \%$ ), 


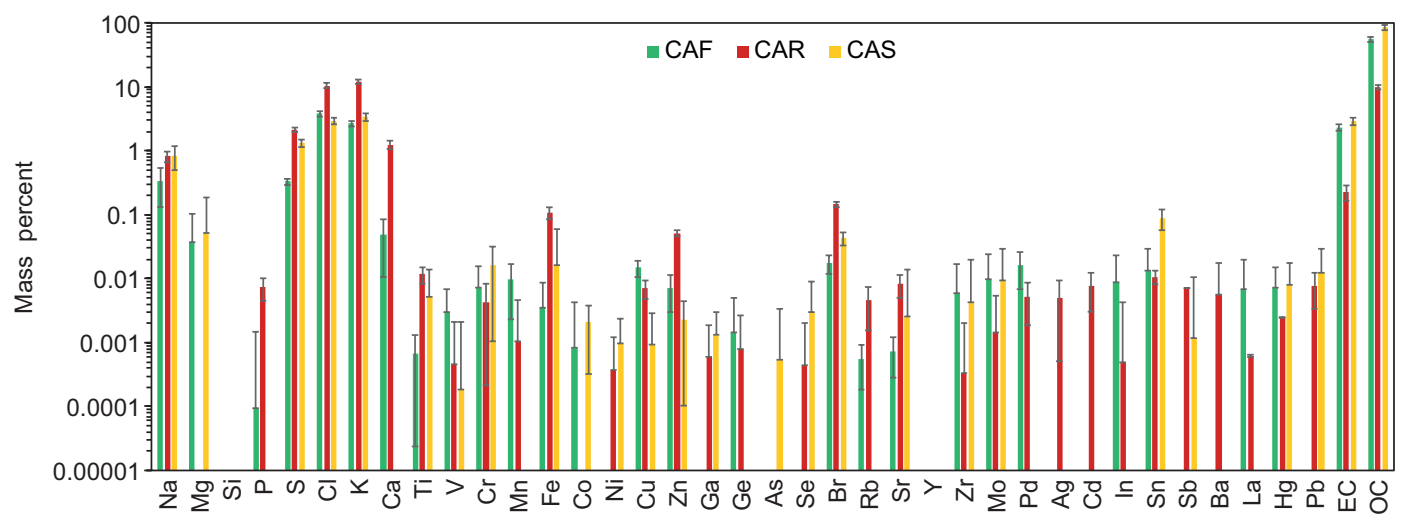

Fig. 3. Profiles for meat cooking operations (see Table I for definitions of acronyms).

Pulong et al. (2017) (Al: $10 \%$; Mg: $0.7 \%$; Fe:1.0\%; $\mathrm{Na}: 5.0 \%$ ), and Wang et al. (2020) (Al: $1.3 \%$; Mg: $11 \%$; Fe: $0.4 \%$; Na: $6.0 \%$ ). In contrast, the $\mathrm{S}, \mathrm{Cl}$, and $\mathrm{K}$ abundances (1-10\%) were higher than those from Pulong et al. (2017) (Cl: $0.45 \% ; \mathrm{K}: 0.64 \%)$ and Wang et al. (2020) (S: $0.5 \%$; Cl: $0.8 \%$; K: $0.4 \%$ ).

In figure 4, the average abundances of the profiles for the two categories of industries are compared. The oil refinery profiles (PMX) were dominated by OC (18-29\%), EC (1.2-3.3\%), S (3.7-5.5\%), and $\mathrm{Na}(1.0-2.5 \%)$. Apart from the carbonaceous species, $\mathrm{Mg}, \mathrm{Al}, \mathrm{Cl}, \mathrm{K}, \mathrm{Ti}, \mathrm{Cr}, \mathrm{Cu}, \mathrm{Mn}, \mathrm{Fe}, \mathrm{Cd}, \mathrm{Sb}$, and $\mathrm{Pb}$ were observable $(<1.0 \%)$. The manufacturing industry profiles (PSN) were dominated by OC (21$22 \%), \mathrm{S}(12-14 \%)$, and EC (1.1-2.2\%). In this case, the following elements were noticeable $(<1.0 \%)$ : $\mathrm{Na}, \mathrm{Mg}, \mathrm{Al}, \mathrm{P}, \mathrm{Cl}, \mathrm{K}, \mathrm{Cr}, \mathrm{Cu}, \mathrm{Mn}, \mathrm{Fe}, \mathrm{Zn}, \mathrm{As}, \mathrm{Br}, \mathrm{Mo}$, $\mathrm{Pd}, \mathrm{Ag}, \mathrm{In}, \mathrm{Sn}$, and $\mathrm{Pb}$. This dominance for both was also observed for the industrial emissions in Mexico City (INECC 2019b). The S contribution in the manufacturing profiles suggests that the manufacturing industries might be using fossil fuels with $\mathrm{S}$ content (e.g., diesel in ancillary systems). In addition, the industries may be using petrochemical materials in their processes. For the oil refinery profiles, the average abundances of EC (2.23\%), $\mathrm{Al}(0.84 \%), \mathrm{Cr}(0.03 \%)$, $\mathrm{Fe}(0.06 \%), \mathrm{Pb}(0.005 \%)$, and $\mathrm{Zn}(0.002 \%)$ were lower than those from Lou et al. (2018), which were $3.0,0.97,0.012,1.18,0.4$, and $0.43 \%$, respectively; in contrast, the levels of OC and S were 20 and $40 \%$ higher than those from Luo et al. (2018). Additionally, as a tracer of heavy oil burning emissions, $V$ was not found in the oil refinery profiles, unlike in cases with similar source profiles (Taiwo et al. 2014, Zhang et al. 2016, Luo et al. 2018, Amoatey et al. 2019). These results are representative of weekdays when industrial activity is normal.

The average abundances for the open-waste burning and urban construction dust profiles are shown in figures 4 and 5 , respectively. The open-waste burning profiles $(\mathrm{QB})$ were dominated by OC (50-52 \%) and EC (44-49\%). Apart from organic tracers, trace elements that are characteristics of organic matter (e.g., wood, grass, meals) and inorganic matter

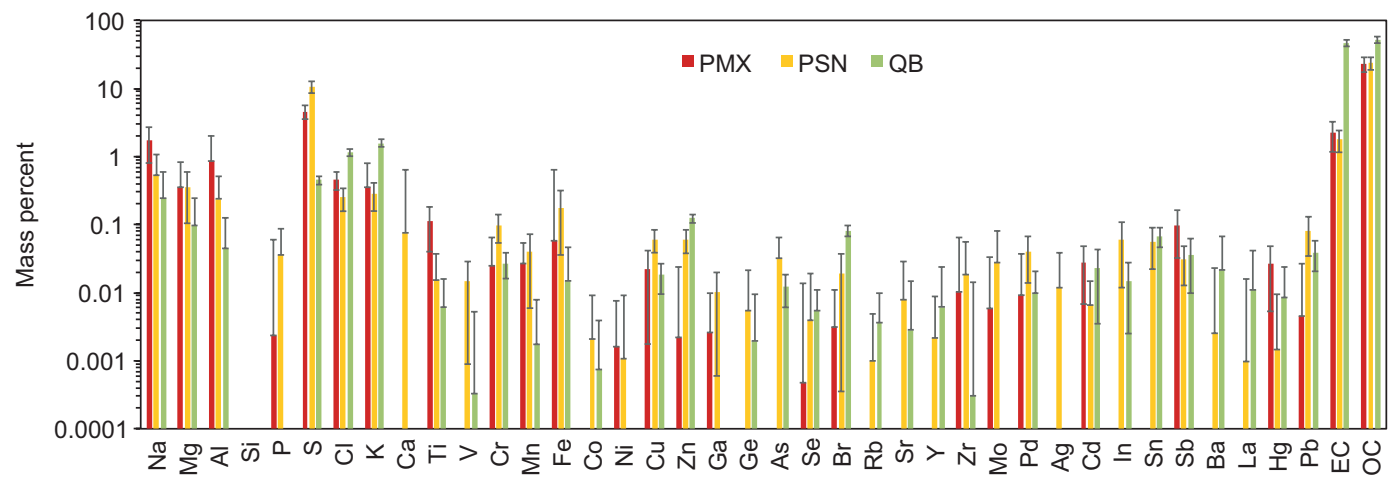

Fig. 4. Profiles for industry emissions and biomass burning (see Table I for definitions of acronyms). 
(e.g., plastics, textiles) were found in these emission profiles. $\mathrm{Cl}$ and $\mathrm{K}$ were present $(1-10 \%)$ as well as $\mathrm{Na}, \mathrm{Mg}$, and $\mathrm{Br}(0.1-1.0 \%)$ for the organic matter (compostable materials) (Maasikmets et al. 2016), while for the inorganic matter (non-compostable materials), the noticeable trace elements (0.1-1.0\%) included $\mathrm{Cr}$, $\mathrm{As}, \mathrm{Cd}, \mathrm{Sn}, \mathrm{Sb}, \mathrm{Hg}$, and $\mathrm{Pb}$. This is different than that observed in Mexico City, where $\mathrm{K}$ and $\mathrm{Pb}$ are the key components of biomass burning (INECC 2019b). The presence of $\mathrm{Hg}$ is associated with the burning or incineration processes of waste (Taiwo et al. 2014, Riffault et al. 2015) that could include discarded household items such as alkaline batteries, button cells, fluorescent lamps, thermometers, and sphygmomanometers, which may contain this element at largely varying levels (Chalkidis et al. 2020). In addition, the presence of OC, $\mathrm{EC}, \mathrm{Cl}, \mathrm{Na}$, and $\mathrm{K}$ is an indicator of biomass burning processes (Tao et al. 2013, Khan et al. 2021). K/EC ratios were used to assess the biomass burning contribution (Khan et al. 2021). The average $\mathrm{K} / \mathrm{EC}$ ratio in this study was 0.033 ; this suggests field grass and wood combustion (Tao et al. 2013, Khan et al. 2021), which agrees with the sampling site for this profile. Unlike in similar source profiles (Zhang et al. 2016, Sun et al. 2019a, Wang et al. 2020), Hg and other non-compostable tracers were found in open-waste burning profiles in the present study. Additionally, the average mass contribution of $\mathrm{K}(1.60 \%)$ was lower than those from Sun et al. (2019a) and Wang et al. (2020), which were 7.10 and $2.39 \%$, respectively.

The urban construction profiles (RP) were dominated by $\mathrm{Ca}(5-7 \%), \mathrm{OC}(10-21 \%)$, and EC (3-8 \%). Other trace elements that were appreciable in these profiles were $\mathrm{Al}(2-3 \%), \mathrm{Fe}(1 \%)$, and $\mathrm{S}(1-7 \%)$. As can be seen in these profiles, the contributions of
$\mathrm{Ca}$ were noticeable and can be an indicator of cement dust emissions, given that cement composition includes calcium silicates along with the presence of Fe, Al, Mg, Zn, As, and Pb (Taiwo et al. 2014, Zhang et al. 2014). A combination of $\mathrm{Zn}$ and $\mathrm{Pb}$ contributions indicates a possible paved road dust resuspension (Riffault et al. 2015). Diagnostic ratios between the trace elements that comprise fugitive dust profiles can be used as markers to track the origins of dust in urban areas (Arimoto et al. 1996, Alfaro et al. 2003, Sun et al. 2019b). In this study, the average ratios of $\mathrm{Ca}, \mathrm{Zn}, \mathrm{Pb}$, and $\mathrm{Fe}$ to $\mathrm{Al}$ were estimated with the following values: $\mathrm{Ca} / \mathrm{Al}=11, \mathrm{Fe} / \mathrm{Al}=0.4, \mathrm{Zn} / \mathrm{Al}=$ 0.22 , and $\mathrm{Pb} / \mathrm{Al}=0.08$. These values are different from those reported for construction dust by Sun et al. (2019b), which were 2.4-4.3, 0.7-1.2, 0.01-0.02, and $0.003-0.01$, respectively. The high ratio of $\mathrm{Ca}$ / $\mathrm{Al}$ suggests a contribution from cement dust given the range values reported by Sun et al. (2019b), which were 6.3-29.5. Finally, different from other construction and fugitive dust profiles (Wang et al. 2015b, Zhang et al. 2016), the profiles in this study exhibited elemental $\mathrm{S}$ that can be associated with the chemical binding of sulfate with crustal elements in the road (Kim and Seinfeld 1995, Wang et al. 2015b).

The average abundances for the suburban background profiles (RT) are shown in figure 5. This profile, more than an emission profile, has the characteristic chemical abundance of air masses being transported from the eastern background region of the MMA. These profiles were dominated by OC (12-19\%), $\mathrm{S}(7-13 \%)$, and EC (1-4 \%). The contribution of elements was found to be in the order of $\mathrm{S}>\mathrm{Na}>$ $\mathrm{Mg}>\mathrm{Al}>\mathrm{Cl}>\mathrm{K}>\mathrm{Cu}>\mathrm{Cr}>\mathrm{Zn}>\mathrm{Ti}>\mathrm{Mn}>\mathrm{Mo}>$ $\mathrm{Pb}$. Of these species, sulfur was the most abundant element. Its major chemical form in these profiles

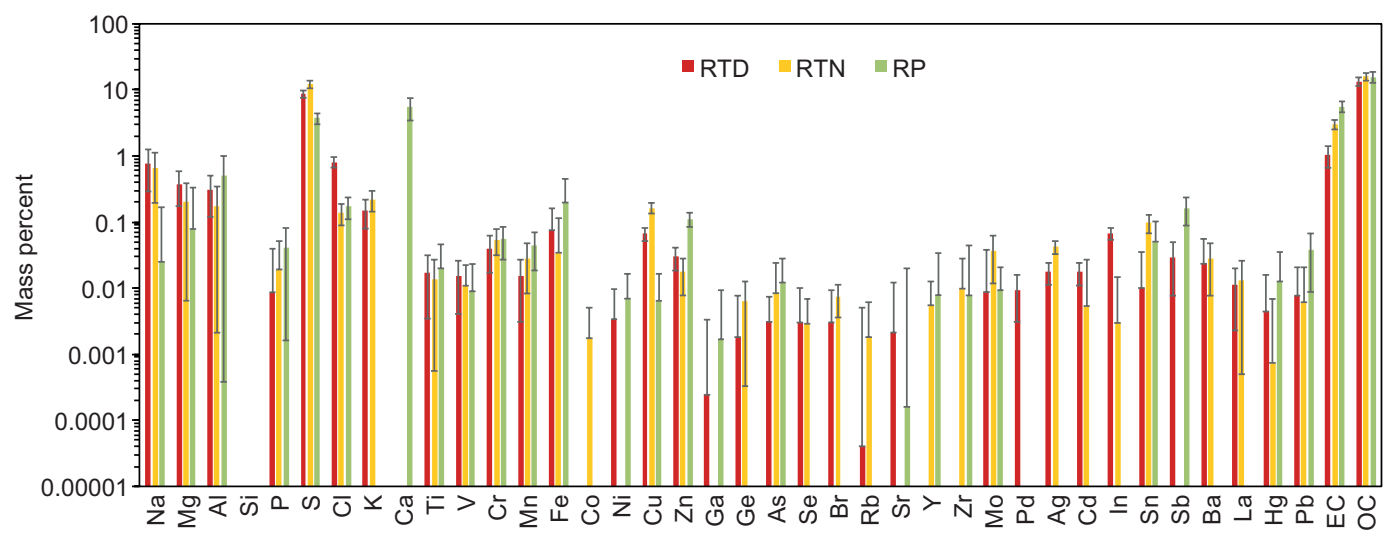

Fig. 5. Profiles for urban background (see Table I for definitions of acronyms). 
may be sulfate, which would be in line with the high OC/EC ratios (photochemically aged background air masses). $\mathrm{Zn}$ and $\mathrm{Pb}$ can be associated with emission coming from paved roads, open-waste burning, or mining industry (Riffault et al. 2015). Unlike the urban construction profile, $\mathrm{Ca}$ and $\mathrm{Fe}$ were not present in the suburban profiles because they represent outskirts areas of the MMA, while the urban construction profiles are associated to an anthropogenic activity inside the MMA.

\section{OC/EC diagnostic ratios}

The OC/EC ratios in table III are consistent within source categories but differ between categories. These consistencies and differences were statistically significant and were estimated by t-tests assuming a normal distribution and unknown variances at significance levels of $0.01,0.05$, and 0.10 .

The ratios for gasoline-fueled vehicles were 1.53.0 times higher than diesel-fueled vehicle ratios. This is related to the fact that EC levels for diesel vehicle exhausts are lower than those for gasoline vehicle exhausts because diesel engines typically have better efficiencies. The ratio for gasoline-fueled vehicles was 50-75\% lower than that reported by other studies. Meanwhile, the OC/EC ratios for diesel-fueled vehicles were both higher and lower than those reported from other studies. These differences between profiles can be associated with vehicle fleet composition, car models, fuel quality, traffic, and driving style, among others.

The average OC/EC ratios for the residential, restaurant, and supermarket cooking operations profiles were higher than those observed from table III; the high ratios in this study can be associated with the quality of the charcoal used and some other complements used to cook meat and burn charcoal. In their cooking operations, supermarkets use natural gas and charcoal, which substantially contribute OC. Additionally, the average EC fraction in the residential and supermarket cooking operations was 10 times higher than that in the restaurant cooking operations.

For the oil refinery and manufacturing industry profiles, the average $\mathrm{OC} / \mathrm{EC}$ ratio was higher than that reported by other studies. Meanwhile, the open-waste burning profiles exhibited lower OC/EC ratios. For the latter profiles, the major difference lies in the presence of inorganic elements (non-compostable materials) which, along with the incomplete combustion of organic compounds, increase EC emissions. The average OC/EC ratio in the construction dust profile was much lower than that from similar profiles. Given that the construction site it could a possible influence of vehicle exhaust and fuel-powered machinery used in the construction site.

Finally, the daytime suburban OC/EC ratio (RTD profile) was three times higher than the nighttime one (RTN profile), which could be related to a secondary organic contribution due to transport emissions, local photochemical oxidation processes in the atmosphere, or presence of mixed vehicle exhaust in the background (Li et al. 2010, Mo et al. 2015, Lai et al. 2016). In addition, these ratios were 2-4 times higher than those for the urban construction profile, supporting the origin of these kind of emissions, anthropogenic for urban construction and naturaltransport for suburban profiles.

\section{Source profile similarity analysis}

The main elemental composition fractions (as a percentage of the total mass) and results from the test of similarity between the source profiles in this study are shown in figures 6 and 7, respectively. Figure 6 indicates broadly that similar emission sources have a similar breakdown of main categories, or similar categories dominate the emissions. Metals dominated the elemental emissions of cooking operations, followed by non-metals. Heavy-duty diesel truck emissions (urban and freight transport) categories were similar, with a major difference in crustal presence with respect to gasoline emissions. The suburban (background) and urban construction site profiles based on the main elemental categories seemed unique and distinct from the other profiles.

Interestingly, the mass concentrations of $\mathrm{Ti}$, $\mathrm{V}, \mathrm{Cr}, \mathrm{Fe}$, and $\mathrm{Zn}$ for the diesel profiles were 1.5-2.0 times higher than those for the gasoline profiles. According to Alves et al. (2015), greater emissions of these elements were generated from heavy vehicles. $\mathrm{Cu}, \mathrm{Zn}$, and $\mathrm{Sb}$ could be emitted from brake and tire wear (Bukowiecki et al. 2009, Srimuruganandam and Nagendra 2011, Riffault et al. 2015, Pant et al. 2017). In the present study, for gasoline-fueled vehicles the $\mathrm{Zn}$ and $\mathrm{Sb}$ contributions were 6 and 1.5 times higher than those for dieselfueled vehicles, rspectively. For the freight transport profiles $(\mathrm{CC})$, one distinguishing element was $\mathrm{Sn}$ (0.09-0.16\%); for the urban transport profiles (TP), $\mathrm{Ag}$ was the distinguishing element (0.09-0.27\%). Meanwhile, for cooking operations, a remarkable result is that the $\mathrm{S}$ fraction in the restaurant and supermarket profiles was up to six times higher than that in the overall contribution to residential cooking operations. This suggests that the content of $\mathrm{S}$ in the charcoal used by the restaurants and supermarkets is relatively high. For the suburban profile, 
TABLE III. AVERAGE OC/EC RATIOS FOR SOURCE PROFILES.

\begin{tabular}{|c|c|c|}
\hline Source profile & $\mathrm{OC} / \mathrm{EC}$ & Reference \\
\hline $\begin{array}{l}\text { Residential charbroiled meat (CAF) } \\
\text { Restaurant charbroiled and grilled meat (CAR) } \\
\text { Supermarket charbroiled meat service (CAS) } \\
\text { Gasoline-fueled vehicles (TLL) } \\
\text { Freight transport - diesel (CC) } \\
\text { Urban transport - diesel (TP) } \\
\text { Oil refinery (PMX) } \\
\text { Manufacturing industry (PSN) } \\
\text { Open-waste burning (QB) } \\
\text { Suburban area in daytime (RTD) } \\
\text { Suburban area in nighttime (RTN) } \\
\text { Urban construction site (RP) }\end{array}$ & $\begin{array}{c}23.74 \pm 3.67 \\
44.16 \pm 12.02 \\
29.88 \pm 4.80 \\
3.30 \pm 1.16 \\
2.16 \pm 1.39 \\
1.16 \pm 0.35 \\
10.42 \pm 5.61 \\
13.35 \pm 5.40 \\
1.11 \pm 0.17 \\
12.85 \pm 5.0 \\
5.23 \pm 1.15 \\
2.81 \pm 0.76\end{array}$ & This study ${ }^{\mathrm{a}}$ \\
\hline $\begin{array}{l}\text { Cooking smoke } \\
\text { Gasoline-fueled vehicles } \\
\text { Garbage-fired power plant } \\
\text { Construction dust }\end{array}$ & $\begin{array}{c}9.29 \\
13.11 \\
2.36 \\
31.7,5.5\end{array}$ & Pulong et al. (2017) \\
\hline $\begin{array}{l}\text { Barbeque (charcoal \& meat) } \\
\text { Household garbage }\end{array}$ & $\begin{array}{c}11.85 \\
7.51\end{array}$ & Wang et al. (2020) \\
\hline $\begin{array}{l}\text { Gasoline-fueled vehicles } \\
\text { Diesel-fueled vehicles }\end{array}$ & $\begin{array}{l}6.08 \\
1.13\end{array}$ & Hao et al. (2019) \\
\hline Biomass burning & $3,6.5,5.0$ & Tao et al. (2013) \\
\hline $\begin{array}{l}\text { Gasoline-fueled vehicles } \\
\text { Diesel-fueled vehicles } \\
\text { Oil-fired power plants } \\
\text { Biomass burning } \\
\text { Construction dust }\end{array}$ & $\begin{array}{c}8.64 \\
2.82 \\
6.1 \\
13.3 \\
19.8\end{array}$ & Zhang et al. (2016) \\
\hline $\begin{array}{l}\text { Gasoline-fueled vehicles } \\
\text { Diesel-fueled vehicles }\end{array}$ & $\begin{array}{c}2.65,10.9 \\
0.33,0.41,0.67\end{array}$ & Kang et al. (2010) \\
\hline Diesel-fueled vehicles & 0.33 & Cui et al. (2017) \\
\hline Vehicles & $0.99,2.7$ & Pant et al. (2017) \\
\hline Diesel-fueled vehicles & 0.55 & Liu et al. (2018b) \\
\hline Petrochemical industry & 7.0 & Luo et al. (2018) \\
\hline Biomass burning (wood \& grass) & 1.9 & Sun et al. (2019a) \\
\hline Construction dust & $3.05,6.85$ & Sun et al. (2019b) \\
\hline Barbeque (charcoal \& meat) & 1.96 & Wang et al. (2015a) \\
\hline
\end{tabular}

${ }^{\mathrm{a} A v e r a g e ~ O C / E C ~ r a t i o s ~ u s i n g ~ i n d i v i d u a l ~ v a l u e s ~ f o r ~ e a c h ~ s o u r c e ~ s a m p l e . ~}$

the average $\mathrm{OC}$ contribution during nighttime was $19 \%$ higher than that during daytime. One reason for this could be the lower ambient temperatures during the night, which reduce the volatilization of the organic compounds emitted from vegetative detritus (Xu et al. 2020). In addition, the average EC contribution during nighttime was twice that during daytime, which could be associated with a local combustion source.

The similarities of all the chemical source profiles were investigated. The profiles were compared with each other using both the PD and SID similarity indicators. This assessment analysis helped to determine whether they were mixing with other emission 


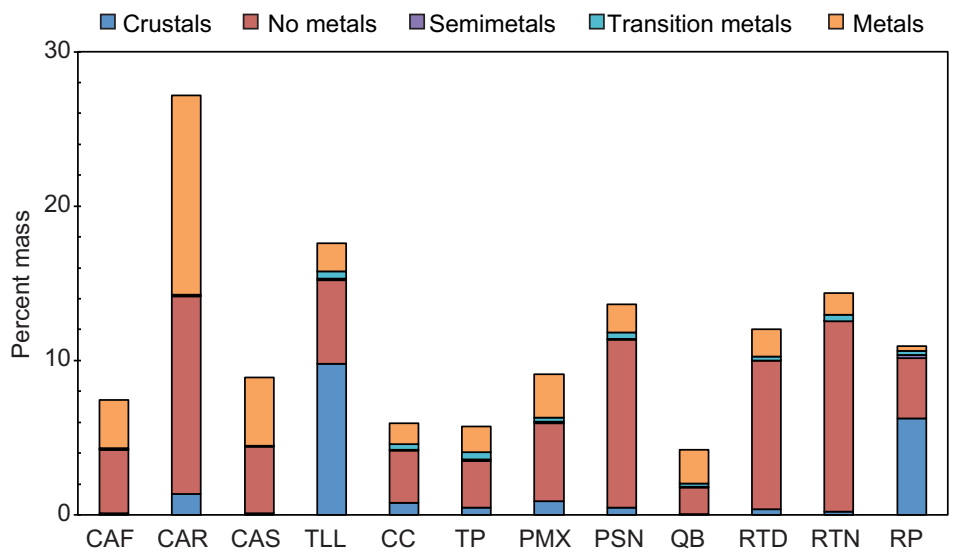

Fig. 6. Main chemical composition of source profiles (mass percent) for $\mathrm{PM}_{2.5}$ in the MMA (see Table I for definitions of acronyms).

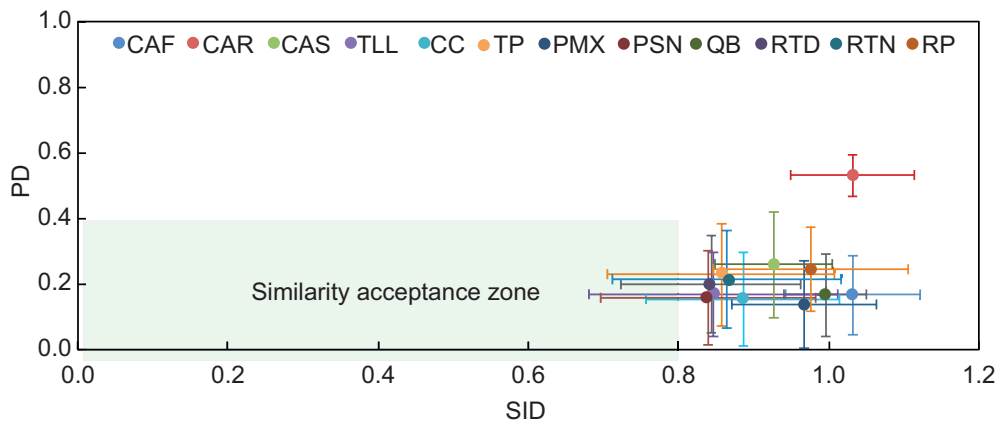

Fig. 7. Similarity plot for all pairs of profiles in this study. The green box highlights the acceptable area for profile similarity according to Weber et al. (2019) (see Table I for definitions of acronyms).

sources. Figure 7 reveals that the average source profiles presented high PD and SID with values outside the acceptance box ( $\mathrm{PD}<0.4$ and SID $<0.8)$, indicating that they were dissimilar (heterogeneous profiles) over the different source profiles of this study. This was expected, as such emissions were collected directly from the source. The variability in the PD-SID space, for those that reached the acceptance box, suggests that some profiles can be slightly mixed, or they may be different from most elements emitted from multiple types of sources, as is expected when the trace element approach is used to distinguish source profiles (Kalaiarasan et al. 2018). The most heterogeneous profiles were those for cooking operations, and the least heterogeneous were those for vehicle exhaust and suburban background. This last result indicates that, indeed, the background profile contains air masses that have received contributions from several sources, including vehicle emissions.

\section{CONCLUSIONS}

The chemical composition of $\mathrm{PM}_{2.5}$ samples collected from 12 anthropogenic sources in the MMA was obtained measuring 38 elements ( $\mathrm{Na}$ to $\mathrm{Pb}$ ) and two carbonaceous species (OC and EC). The source profiles of these sources were generally distinguishable, as determined by PD and SID for each pair of source profiles. Gasoline-fueled vehicles and construction dust were characterized by a particularly large contribution of crustal elements in comparison with the contribution of the other source profiles. Meanwhile, in the meat cooking operations, the transition metals were barely noticeable, unlike those in the other source profiles. The OC/EC diagnosis helped characterize primary emission sources; these ratios were found to be in the order of CAR $>$ CAS $>\mathrm{CAF}>\mathrm{PSN}>\mathrm{RTD}>\mathrm{PMX}>\mathrm{RTN}>\mathrm{TLL}>\mathrm{RP}$ $>\mathrm{CC}>\mathrm{TP}>\mathrm{QB}$, and they were statistically different between source emissions. Furthermore, the key 
components of each source profile seem to be slightly different from those in other Mexican cities in which source apportionment studies have been conducted. These profiles could further be used in receptor models, such as CMB models, to conduct source apportionment for ambient $\mathrm{PM}_{2.5}$ samples collected at different locations within the MMA or urban centers with similar emission source conditions.

\section{ACKNOWLEDGMENTS}

This work was supported by the Mexican National Council for Science and Technology (CONACYT) through grant number CB-2010-154122. Gerardo E. Medina received additional support (scholarship, grant number 293926) through CONACYT.

\section{SUPPLEMENTARY MATERIAL}

Auxiliary information to aid the interpretation of this article can be found in the supplementary material provided at the end of this article.

\section{REFERENCES}

Alfaro S.C., Gomes L., Rajot J.L., Lafon S., Gaudichet A., Chatenet B., Maille M., Cautenet G., Lasserre F., Cachier H. and Zhang X.Y. (2003). Chemical and optical characterization of aerosols measured in spring 2002 at the ACE-Asia supersite, Zhenbeitai, China. J. Geophys. Res. Atmos. 108(D23), 8641. https://doi. org/10.1029/2002JD003214

Alves C.A., Lopes D.J., Calvo A.I., Evtyugina M., Rocha S. and Nunes T. (2015). Emissions from lightduty diesel and gasoline in-use vehicles measured on chassis dynamometer test cycles. Aerosol Air. Qual. Res. 15(1), 99-116. https://doi.org/10.4209/ aaqr.2014.01.0006

Amoatey P., Omidvarborna H., Baawain M.S. and AlMamun A. (2019). Emissions and exposure assessments of SOx, NOx, $\mathrm{PM}_{10 / 2.5}$ and trace metals from oil industries: a review study (2000-2018). Process. Saf. Environ. 123, 215-228. https://doi.org/10.1016/j. psep.2019.01.014

Anake W.U., Benson N. U., Tenebe I. T., Emenike P. C., Ana G. R. E. E. and Zhang S. (2020). Chemical speciation and health risks of airborne heavy metals around an industrial community in Nigeria. Hum. Ecol. Risk. Assess. 26(1), 242-254. https://doi.org/10.1080/1080 7039.2018.1504672
Araizaga A.E., Mancilla Y. and Mendoza A. (2013). Volatile organic compound emissions from light-duty vehicles in Monterrey, Mexico: a tunnel study. Int. J. Environ. Res. 7(2), 277-292. https://doi.org/ 10.22059/ IJER.2013.607

Arimoto R., Duce R.A., Savoie D.L., Prospero J.M., Talbot R., Cullen J.D., Tomza U., Lewis N.F. and Ray B.J. (1996). Relationships among aerosol constituents from Asia and the North Pacific during PEM-West A. J. Geophys. Res. Atmos. 101(D1), 2011-2023 (19842012). https://doi.org/10.1029/95JD01071

Badillo-Castañeda C.T., Garza-Ocañas L., Garza-Ulloa M.C.H., Zanatta-Calderón M.T. and CaballeroQuintero A. (2015). Heavy metal content in $\mathrm{PM}_{2.5}$ air samples collected in the Metropolitan Area of Monterrey, Mexico. Hum. Ecol. Risk. Assess. 21(8), 20222035. https://doi.org/10.1080/10807039.2015.1017873

Belis C.A., Pernigotti D., Karagulian F., Pirovano G., Larsen B., Gerboles M. and Hopke P. (2015). A new methodology to assess the performance and uncertainty of source apportionment models in intercomparison exercises. Atmos. Environ. 119, 35-44. https://doi. org/10.1016/j.atmosenv.2015.08.002

Blanco-Jiménez S., Altúzar F., Jiménez B., Aguilar G., Pablo M. and Benítez M.A. (2015). Evaluación de partículas suspendidas $\mathrm{PM}_{2.5}$ en el Área Metropolitana de Monterrey. Instituto Nacional de Ecología y Cambio Climático, México, 34 pp.

Birch M.E. and Cary R.A. (1996). Elemental carbon-based method for monitoring occupational exposures to particulate diesel exhaust. Aerosol Sci. Technol. 25(3), 221-241. https://doi.org/10.1080/02786829608965393

Bukowiecki N., Lienemann P., Hill M., Figi R., Richard A., Furger M., Rickers K., Falkenberg G., Zhao Y., Cliff S.S., H. Prevot A.S., Baltensperger U., Buchmann B. and Gehrig R. (2009). Real-world emission factors for antimony and other brake wear related trace elements: size-segregated values for light and heavy duty vehicles. Environ. Sci. Technol. 43(21), 8072-8078. https://doi.org/ 10.1021/es9006096.

Cabada J.C., Spyros N.P., Subramanian R., Robinson A.L., Polidori A. and Turpin B. (2004). Estimating the secondary organic aerosol contribution to $\mathrm{PM}_{2.5}$ using the EC tracer method. Aerosol Sci. Technol. 38(1), 140-155. https://doi.org/10.1080/02786820390229084

Chalkidis A., Jampaiah D., Aryana A., Wood C.D., Hartley P.G., Sabri Y.M. and Bhargava S.K. (2020). Mercury-bearing wastes: sources, policies and treatment technologies for mercury recovery and safe disposal. J. Environ. Manage. 270, 110945. https:// doi.org/10.1016/j.jenvman.2020.110945

Chow J.C., Watson J.G., Kuhns H., Etyemezian V., Lowenthal D.H., Crow D., Kohl S.D., Engelbrecht J.P. 
and Green M.C. (2004). Source profiles for industrial, mobile, and area sources in the Big Bend Regional Aerosol Visibility and observational study. Chemosphere 54(2), 185-208. https://doi.org/10.1016/j. chemosphere.2003.07.004

Chow J.C., Watson J.G., Lowenthal D.H., Chen L.-W.A. and Motallebi N. (2010). Black and organic carbon emission inventories: review and application to California. J. Air Waste Manage. 60(4), 497-507. https:// doi.org/ 10.3155/1047-3289.60.4.497

Cui M., Chen Y.J., Feng Y.L., Li C., Zheng J.Y., Tian C.G., Yan C.Q. and Zheng M. (2017). Measurement of PM and its chemical composition in real-world emissions from non-road and on-road diesel vehicles. Atmos. Chem. Phys. 17(11), 6779-6795. https://doi. org/10.5194/acp-17-6779-2017

Feng Y., Chen Y., Guo H., Zhi G., Xiong S., Li J., Sheng G. and Fu J. (2009). Characteristics of organic and elemental carbon in $\mathrm{PM}_{2.5}$ samples in Shanghai, China. Atmos. Res. 92(4), 434-442. https://doi.org/10.1016/j. atmosres.2009.01.003

Grahame T.J., Klemm R. and Schlesinger R.B. (2014). Public health and components of particulate matter: The changing assessment of black carbon. J. Air Waste Manage. 64(6), 620-660. https://doi.org/10.1080/109 62247.2014 .912692

Hao Y., Gao C., Deng S., Yuan M., Song W., Lu Z. and Qiu Z. (2019). Chemical characterization of $\mathrm{PM}_{2.5}$ emitted from motor vehicles powered by diesel, gasoline, natural gas and methanol fuel. Sci. Total Environ. 674, 128-139. https://doi.org/10.1016/j. scitotenv.2019.03.410

Hayes P.L., Ortega A.M., Cubison M.J., Froyd K.D., Zhao Y., Cliff S.S., Hu W.W., Toohey D.W., Flynn J.H., Lefer B. L., Grossberg N., Alvarez S., Rappenglück B., Taylor J.W., Allan J.D., Holloway J.S., Gilman J.B., Kuster W.C., de Gouw J. A., Massoli P., Zhang X., Liu J., Weber R. J., Corrigan A. L., Russell L.M., Isaacman G., Worton D.R., Kreisberg N.M., Goldstein A.H., Thalman R., Waxman E.M., Volkamer R., Lin Y.H., Surratt J.D., Kleindienst T.E., Offenberg J.H., Dusanter S., Griffith S., Stevens P.S., Brioude J., Angevine W.M. and Jimenez J.L. (2013). Organic aerosol composition and sources in Pasadena, California during the 2010 CalNex campaign. J. Geophys. Res. 118(16), 92339257. https://doi.org/10.1002/jgrd.50530

Hopke P.K., Dai Q., Li L. and Feng Y. (2020). Global review of recent source apportionment for airborne particulate matter. Sci. Total Environ. 740, 140091. https://doi.org/10.1016/j.scitotenv.2020.140091

Hoyle C.R., Boy M., Donahue N.M., Fry J.L., Glasius M., Guenther A., Hallar A.G., Huff Hartz K., Petters M.D., Petäjä T., Rosenoern T. and Sullivan A.P. (2011).
A review of the anthropogenic influence on biogenic secondary organic aerosol. Atmos. Chem. Phys. 11(1), 321-343. https://doi.org/10.5194/acp-11-321-2011

INECC (2018a). Evaluación de contaminantes atmosféricos en San Luis Potosí, San Luis Potosí. Instituto Nacional de Ecología y Cambio Climático, Mexico, 32 pp.

INECC (2018b). Determinación de línea base de carbono negro y flujos de dióxido de carbono en Ciudad Juárez, Chihuahua. Instituto Nacional de Ecología y Cambio Climático, Mexico, 11 pp.

INECC (2019a). Informe Nacional de Calidad del Aire 2018, México. Instituto Nacional de Ecología y Cambio Climático, Mexico, 395 pp.

INECC (2019b). Informe de la campaña de medición semiautomática de especies químicas en PM2.5 al suroeste de la ciudad de México. Instituto Nacional de Ecología y Cambio Climático, Mexico, 36 pp.

INECC (2019c). Impacto ambiental del contenido de azufre en el diésel vehicular comercializado en México. Instituto Nacional de Ecología y Cambio Climático, Mexico, $26 \mathrm{pp}$.

INEGI (2015). Censos económicos 2014 [en línea]. https:// www.inegi.org.mx/contenidos/programas/ce/2014/ doc/pprd_ce2014.pdf 07/03/2021

INEGI (2017). Sistema de cuentas nacionales de México [en línea]. https://www.inegi.org.mx/contenidos/ programas/pibact/2013/metodologias/METODOLOGIA_CBYSB2013.pdf 07/03/2021

INEGI (2020). Vehículos de motor registrados en circulación del año 2018 [en línea]. https://www. inegi.org.mx/programas/vehiculosmotor/default. html\#Tabulados 07/03/2021

Kalaiarasan G., Balakrishnan R.M., Sethunath N.A. and Manoharan S. (2018). Source apportionment studies on particulate matter $\left(\mathrm{PM}_{10}\right.$ and $\left.\mathrm{PM}_{2.5}\right)$ in ambient air urban Mangalore, India. J. Environ. Manage. 217, 815824. https://doi.org/10.1016/j.jenvman.2018.04.040

Kang B.-W., Cho M.-S., Lee S.-B., Bae G.-N., Lim C.S., Na K. and Lee H.S. (2010). A study on the source profile development for diesel and gasoline-powered vehicles. J. Korean Soc. Atmos. 26(3), 318-329.

Karagulian F., Belis C.A., Dora C.F., Prüss-Ustün A.M., Bonjour S., Adair-Rohani H. and Amann M. (2015). Contributions to cities' ambient particulate matter (PM): a systematic review of local source contributions at global level. Atmos. Environ. 120, 475-483. https:// doi.org/10.1016/j.atmosenv.2015.08.087

Khan J.Z., Sun L., Tian Y., Shi G. and Feng Y. (2021). Chemical characterization and source apportionment of $\mathrm{PM}_{1}$ and $\mathrm{PM}_{2.5}$ in Tianjin, China: impacts of biomass burning and primary biogenic sources. J. Environ. Sci. 99, 196-209. https://doi.org/10.1016/j. jes.2020.06.027 
Kim Y.P. and Seinfeld J.H. (1995). Atmospheric gas-aerosol equilibrium: III. Thermodynamics of crustal elements $\mathrm{Ca}^{2+}, \mathrm{K}^{+}$, and $\mathrm{Mg}^{2+}$. Aerosol Sci. Technol. 22(1), 93-110. https://doi.org/10.1080/02786829408959730

Kirrane E.F., Luben T.J., Benson A., Owens E.O., Sacks J.D., Dutton S.J., Madden M. and Nichols J.L. (2019). A systematic review of cardiovascular responses associated with ambient black carbon and fine particulate matter. Environ. Int. 127, 305-316. https:// doi.org/10.1016/j.envint.2019.02.027

Lai S., Zhao Y., Ding A., Zhang Y., Song T., Zheng J., Ho K.F., Lee S.-C. and Zhong L. (2016). Characterization of $\mathrm{PM}_{2.5}$ and the major chemical components during a 1-year campaign in rural Guangzhoy, Southern China. Atmos. Res. 167, 208-215. https://doi.org/10.1016/j. atmosres.2015.08.007

Li L., Wang W., Feng J., Zhang D., Li H., Gu Z., Wang B., Sheng G. and Fu J. (2010). Composition, source, mass closure of $\mathrm{PM}_{2.5}$ aerosols for four forests in eastern China. J. Environ. Sci. 22(3), 405-412. https://doi. org/10.1016/S1001-0742(09)60122-4

Liu Y., Xing J., Wang S., Fu X. and Zheng H. (2018a). Source-specific speciation profiles of $\mathrm{PM}_{2.5}$ for heavy metals and their anthropogenic emissions in China. Environ. Pollut. 239, 544-553. https://doi.org/10.1016/j. envpol.2018.04.047

Liu Y., Zhang W., Yang W., Bai Z. and Zhao X. (2018b). Chemical compositions of $\mathrm{PM}_{2.5}$ emitted from diesel trucks and construction equipment. Aerosol Sci. Eng. 2, 51-60. https://doi.org/10.1007/s41810017-0020-2

Luo Y., Zhou X., Zhang J., Xiao Y., Wang Z., Zhou Y. and Wang W. (2018). $\mathrm{PM}_{2.5}$ pollution in a petrochemical industry city of northern China: seasonal variation and source apportionment. Atmos. Res. 212, 285-295. https://doi.org/10.1016/j.atmosres.2018.05.029

Maasikmets M., Kupri H.-L., Teinemaa E., Vainumäe K., Arumäe T., Roots O. and Kimmel V. (2016). Emissions from burning municipal solid waste and Wood in domestic heaters. Atmos. Pollut. Res. 7(3), 438-446. https://doi.org/10.1016/j.apr.2015.10.021

Mancilla Y., Herckes P., Fraser M.P. and Mendoza A. (2015). Secondary organic aerosol contributions to $\mathrm{PM}_{2.5}$ in Monterrey, Mexico: Temporal and seasonal variation. Atmos. Res. 153, 348-359. https://doi. org/10.1016/j.atmosres.2014.09.009

Mancilla Y., Mendoza A., Fraser M.P. and Herckes P. (2016). Organic composition and source apportionment of fine aerosol at Monterrey, Mexico, based on organic markers. Atmos. Chem. Phys. 16(2), 953-970. https:// doi.org/10.5194/acp-16-953-2016

Mancilla Y., Hernandez Paniagua I.Y. and Mendoza A. (2018). Spatial differences in ambient coarse and fine particles in the Monterrey metropolitan area, Mexico: Implications for source contribution. J. Air Waste Manage. 69(5), 548-564. https://doi.org/10.1080/109 62247.2018.1549121

Martínez-Cinco M., Santos-Guzmán J. and Mejía-Velázquez G. (2016). Source apportionment of $\mathrm{PM}_{2.5}$ for supporting control strategies in the Monterrey Metropolitan Area, Mexico. J. Air Waste Manage. 66(6), 631642. https://doi.org/ 10.1080/10962247.2016.1159259

Miller A.J., Raduma D.M., George L.A. and Fry J.L. (2019). Source apportionment of trace elements and black carbon in an urban industrial area (Portland, Oregon). Atmos. Pollut. Res. 10(3), 784-794. https:// doi.org/10.1016/j.apr.2018.12.006

Mo H., Li L., Lai W., Zhao M., Pu J., Zhou Y. and Deng S. (2015). Characterization of summer $\mathrm{PM}_{2.5}$ aerosols from four forest areas in Sichuan, SW China. Particuology 20, 94-103. https://doi.org/10.1016/j. partic.2014.10.009

Mohr C., Huffman A., Cubison M., Aiken A., Docherty K., Kimmel J., Ulbrich I. M., Hannigan M. and Jimenez J.L. (2009). Characterization of primary organic aerosol emissions from meat cooking, trash burning, and motor vehicles with high-resolution aerosol mass spectrometry and comparison with ambient and chamber observations. Environ. Sci. Technol. 43(7), 2443-2449. https://doi.org/10.1021/es8011518

Pant P., Shi Z., Pope F.D. and Harrison R.M. (2017). Characterization of traffic-related particulate matter emissions in a road tunnel in Birmingham, UK: trace metals and organic molecular markers. Aerosol Air Qual. Res. 17(1), 117-130. https://doi.org/10.4209/ aaqr.2016.01.0040

Pernigotti D., Belis C.A. and Spanó L. (2016). SPECEUROPE: The European data base for PM source profiles. Atmos. Pollut. Res. 7, 307-314. https://doi. org/10.1016/j.apr.2015.10.007

Pope C.A., Brook R.D., Burnett R.T. and Dockery D.W. (2011). How is cardiovascular disease mortality risk affected by duration and intensity of fine particulate matter exposure? An integration of the epidemiologic evidence. Air Qual. Atmos. Health 4, 5-14. https://doi. org/10.1007/s11869-010-0082-7

SEDESU (2016). Programa de gestión para mejorar la calidad del aire del Estado de Nuevo León ProAire 2016-2025. Secretaría de Desarrollo Sustentable del Estado de Nuevo León, Mexico, 249 pp.

Pulong C., Tijian W., Mei D., Kasoar M., Yong H., Min X., Shu L., Bingliang Z., Mengmeng L. and Tunan H. (2017). Characterization of major natural and anthropogenic source profiles for size-fractionated PM in Yangtze River delta. Sci. Total Environ. 598, 135145. https://doi.org/10.1016/j.scitotenv.2017.04.106 
Rehman W.U., Park M., Chong J., Lee K., Jang J. and Park K. (2020). Determination of sources of fine particles in different ambient atmospheres in South Korea using a chemical mass balance model. Environ. Forensics 21(1), 48-58. https://doi.org/10.1080/15275922.201 9.1694099

Riffault V., Arndt J., Marris H., Mbengue S., Setyan A., Alleman L. Y., Deboudt K., Flament P., Augustin P., Delbarre H. and Wenger J. (2015). Fine and ultrafine particles in the vicinity of industrial activities: a review. Crit. Rev. Env. Sci. Technol. 45(21), 2305-2356. https://doi.org/10.1080/10643389.2015.1025636

Singh N., Murari V., Kumar M., Barman S.C. and Banerjee T. (2017). Fine particulates over south ASIA: review and meta-analysis of $\mathrm{PM}_{2.5}$ source apportionment through receptor model. Environ. Pollut. 223, 121-136. https://doi.org/10.1016/j.envpol.2016.12.071

Srimuruganandam B. and Nagendra S.M.S. (2011). Chemical characterization of $\mathrm{PM}_{10}$ and $\mathrm{PM}_{2.5}$ mass concentrations emitted by heterogeneous traffic. Sci. Total Environ. 409(17), 3144-3157. https://doi. org/10.1016/j.scitotenv.2011.04.042

Sun J., Shen Z., Zhang Y., Zhang Q., Lei Y., Huang Y., Niu X., Xu H., Cao J., Ho S.S.H. and Li X. (2019a). Characterization of $\mathrm{PM}_{2.5}$ source profiles from typical biomass burning of maize straw, wheat straw, wood branch, and their processed products (briquette and charcoal) in China. Atmos. Environ. 205, 36-45. https://doi.org/10.1016/j.atmosenv.2019.02.038

Sun J., Shen Z., Zhang L., Lei Y., Gong X., Zhang Q., Zhang T., Xu H., Cui S., Wang Q., Cao J., Zhang N. and Zhang R. (2019b). Chemical source profiles of urban fugitive dust $\mathrm{PM}_{2.5}$ samples from 21 cities across China. Sci. Total Environ. 649, 1045-1053. https://doi. org/10.1016/j.scitotenv.2018.08.374

Susaya J., Kim K.-H., Ahn J.-W., Jung M.-C. and Kang C.H. (2010). BBQ charcoal combustion as an important source of trace metal exposure to humans. J. Hazar. Mater. 176(1-3), 932-937. https://doi.org/10.1016/j. jhazmat.2009.11.129

Taiwo A.M., Harrison R.M. and Shi Z. (2014). A review of receptor modelling of industrially emitted particulate matter. Atmos. Environ. 97, 109-120. https://doi. org/10.1016/j.atmosenv.2014.07.051

Tao J., Zhang L., Engling G., Zhang R., Yang Y., Cao J., Zhu C., Wang Q. and Luo L. (2013). Chemical composition of $\mathrm{PM}_{2.5}$ in an urban environment in Chengdu, China: importance of springtime dust storms and biomass burning. Atmos. Res. 122, 270-283. https://doi. org/10.1016/j.atmosres.2012.11.004

Taylor J.R. (1997). An introduction to error analysis: The study of uncertainties in physical measurements. 2nd ed. University Science Books, California, 327 pp.
US-EPA (2004). EPA-CMB8.2 User's Manual. Report No. EPA-452/R-04-011. U.S. Environmental Protection Agency, Research Triangle Park, NC, USA, $123 \mathrm{pp}$.

Vicente E.D., Vicente A., Evtyugina M., Carvalho R., Tarelho L.A.C., Oduber F.I. and Alves C. (2018). Particulate and gaseous emissions from charcoal combustion in barbecue grills. Fuel Process. Technol. 176, 296-306. https://doi.org/10.1016/j.fuproc.2018.03.004

Wang L.L., Lin L. and Chen Y.H. (2011). Determination of lead, arsenic, manganese, cadmium, chromium, copper and other elements in edible oil using direct sampling by ICP-MS. Environ. Chem. 30, 571-573.

Wang G., Cheng S., Wei W., Wen W., Wang X. and Yao S. (2015a). Chemical characteristics of fine particles emitted from different Chinese cooking styles. Aerosol Air Qual. Res. 15(6), 2357-2366. https://doi.org/10.4209/ aaqr.2015.02.0079

Wang X., Chow J.C., Kohl S., Percy K. E., Legge A.H. and Watson J.G. (2015b). Characterization of $\mathrm{PM}_{2.5}$ and $\mathrm{PM}_{10}$ fugitive dust source profiles in the Athabasca oil sands region. J. Air Waste Manage. 65(12), 14211433. https://doi.org/10.1080/10962247.2015.1100693

Wang J., Niu X., Sun J., Zhang Y., Zhang T., Shen Z., Zhang Q., Xu H., Li X. and Zhang R. (2020). Source profiles of $\mathrm{PM}_{2.5}$ emitted from four typical open burning sources and its cytotoxicity to vascular smooth muscle cells. Sci. Total Environ. 715, 136949. https:// doi.org/10.1016/j.scitotenv.2020.136949

Weber S., Salameh D., Albinet A., Alleman L.Y., Waked A., Besombes J.-L., Jacob V., Guillaud G., Meshbah B., Rocq B., Hulin A., Dominik-Sègue M., Chrétien E., Jaffrezo J.-L. and Favez O. (2019). Comparison of $\mathrm{PM}_{10}$ sources profiles at 15 French sites using a harmonized constrained positive matrix factorization approach. Atmosphere 10(6), 310. https://doi. org/10.3390/atmos 10060310

WHO (2016). World health statistics 2016: monitoring health for the SDGs, sustainable development goals. World Health Organization [en línea]. https://apps. who.int/iris/handle/10665/206498 07/03/2021

Xie M., Hannigan M.P., Dutton S.J., Milford J.B., Hemann J.G., Miller S.L., Schauer J.J., Peel J.L. and Vedal S. (2012). Positive Matrix Factorization of $\mathrm{PM}_{2.5}$ : comparison and implications of using different speciation data sets. Environ. Sci. Technol. 46(21), 11962-11970. https://doi.org/10.1021/es302358g

Xu Y., Chen Y., Gao J., Zhu S., Ying Q., Hu J., Wang P., Feng L., Kang H. and Wang. D. (2020). Contribution of biogenic sources to secondary organic aerosol in the summertime in Shaanxi, China. Chemosphere 254, 126815. https://doi.org/10.1016/j.chemosphere.2020.126815 
Yan C., Zheng M., Shen G., Cheng Y., Ma S., Sun J., Cui M., Zhang F., Han Y. and Chen Y. (2019). Characterization of carbon fractions in carbonaceous aerosols from typical fossil fuel combustion sources. Fuel 254, 115620. https://doi.org/10.1016/j.fuel.2019.115620

Yang S., Fang D. and Chen B. (2019). Human health impact and economic effect for $\mathrm{PM}_{2.5}$ exposure in typical cities. Appl. Energ. 249, 316-325. https://doi. org/10.1016/j.apenergy.2019.04.173

Zhang Q., Shen Z., Cao J., Ho K., Zhang R., Bie Z., Chang H. and Liu S. (2014). Chemical profiles of urban fugitive dust over Xi'an in the south margin of the Loess Plateau, China. Atmos. Pollut. Res. 5(3), 421-430. https://doi.org/10.5094/APR.2014.049
Zhang Y., Wang X., Li G., Yang W., Huang Z., Zhang Z., Huang X., Deng W., Liu T., Huang Z. and Zhang Z. (2015). Emission factors of fine particles, carbonaceous aerosols and traces gases from road vehicles: recent tests in an urban tunnel in the Pearl River Delta, China. Atmos. Environ. 122, 876-884. https://doi. org/10.1016/j.atmosenv.2015.08.024

Zhang N., Zhuang M., Tian J., Tian P., Zhang J., Wang Q., Zhou Y., Huang R., Zhu C., Zhang X. and Cao J. (2016). Development of source profiles and their application in source apportionment of $\mathrm{PM}_{2.5}$ in Xiamen, China. Front. Environ. Sci. Eng. 10, 17. https://doi. org/10.1007/s11783-016-0879-1

Zhao Y., Chen C. and Zhao B. (2019). Emission characteristics of $\mathrm{PM}_{2.5}$-bound chemicals from residential Chinese cooking. Build. Environ. 149, 623-629. https:// doi.org/10.1016/j.buildenv.2018.12.060 


\section{SUPPLEMENTARY MATERIAL}

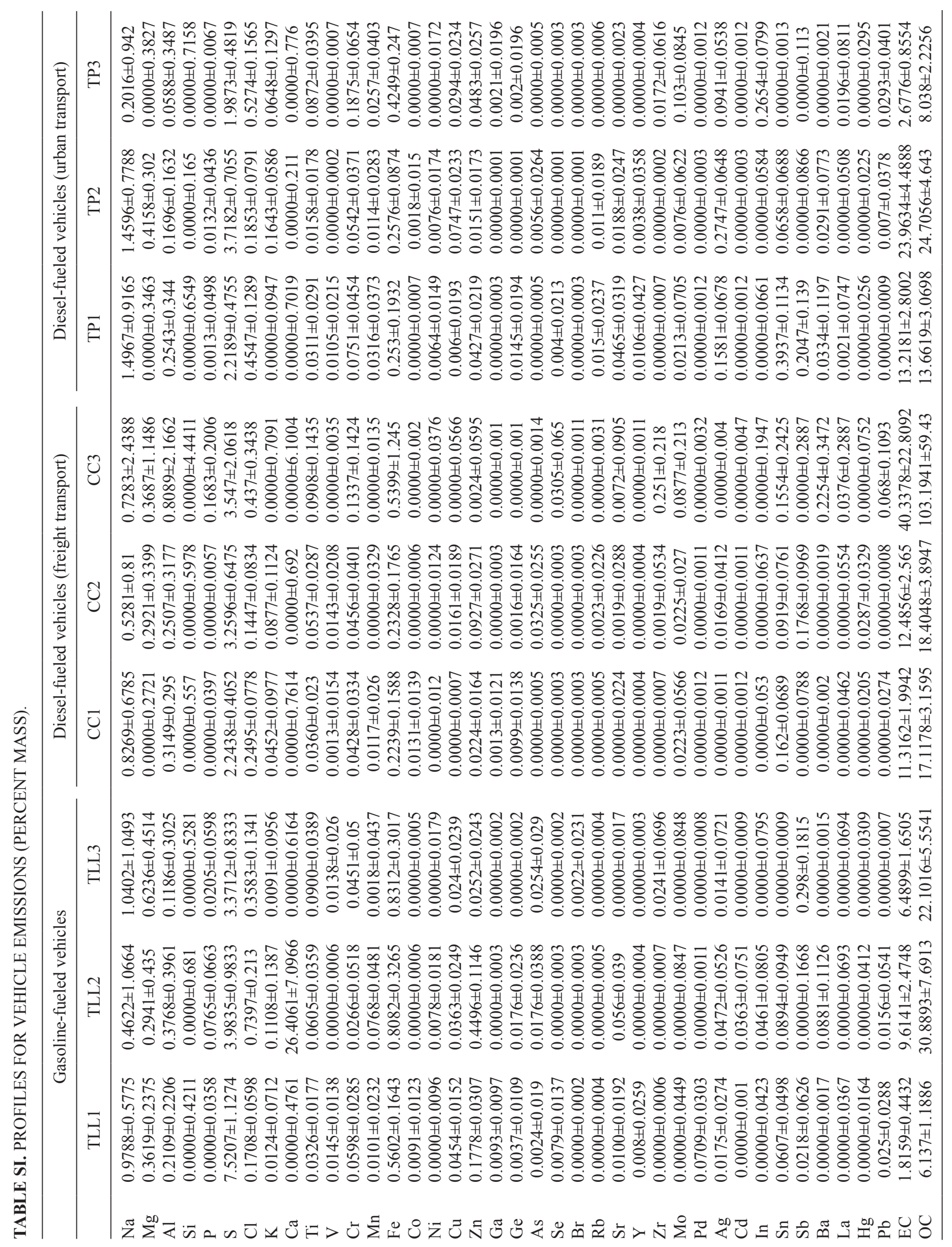


TABLE SII. PROFILES FOR MEAT COOKING EMISSIONS (PERCENT MASS).

\begin{tabular}{|c|c|c|c|c|c|c|}
\hline & \multicolumn{2}{|c|}{ Residential charbroiled meat } & \multicolumn{2}{|c|}{ Restaurant charbroiled and grilled meat } & \multicolumn{2}{|c|}{ Supermarket charbroiled service } \\
\hline & CAF1 & CAF2 & CAR1 & CAR2 & CAS1 & CAS2 \\
\hline $\mathrm{Na}$ & $0.1393 \pm 0.3367$ & $0.5294 \pm 0.0674$ & $0.2232 \pm 0.079$ & $1.4161 \pm 0.238$ & $1.1764 \pm 0.5228$ & $0.5081 \pm 0.17$ \\
\hline $\mathrm{Mg}$ & $0.0731 \pm 0.1345$ & $0.0000 \pm 0.0007$ & $0.0000 \pm 0.0301$ & $0.0000 \pm 0.0718$ & $0.0895 \pm 0.1998$ & $0.0142 \pm 0.0637$ \\
\hline $\mathrm{Al}$ & $0.0991 \pm 0.0675$ & $0.0027 \pm 0.0067$ & $0.0000 \pm 0.0308$ & $0.0000 \pm 0.0395$ & $0.1432 \pm 0.1529$ & $0.0495 \pm 0.0439$ \\
\hline $\mathrm{Si}$ & $0.0000 \pm 0.0510$ & $0.0000 \pm 0.0073$ & $0.0000 \pm 0.0771$ & $0.0000 \pm 0.0568$ & $0.0000 \pm 0.2619$ & $0.0000 \pm 0.0685$ \\
\hline $\mathrm{P}$ & $0.0000 \pm 0.0005$ & $0.0002 \pm 0.0022$ & $0.0148 \pm 0.0052$ & $0.0000 \pm 0.0006$ & $0.0000 \pm 0.0026$ & $0.0000 \pm 0.0007$ \\
\hline $\mathrm{S}$ & $0.4099 \pm 0.0543$ & $0.2503 \pm 0.0223$ & $1.7661 \pm 0.1554$ & $2.5048 \pm 0.2304$ & $1.7839 \pm 0.2571$ & $0.8436 \pm 0.0818$ \\
\hline $\mathrm{Cl}$ & $2.3399 \pm 0.273$ & $5.2164 \pm 0.4592$ & $4.209 \pm 0.3696$ & $16.7898 \pm 1.5358$ & $4.1778 \pm 0.5873$ & $1.775 \pm 0.1679$ \\
\hline $\mathrm{K}$ & $2.7189 \pm 0.3147$ & $2.6221 \pm 0.2332$ & $7.8565 \pm 0.6947$ & $16.2906 \pm 1.4945$ & $4.7756 \pm 0.6925$ & $1.9405 \pm 0.1879$ \\
\hline $\mathrm{Ca}$ & $0.0676 \pm 0.0652$ & $0.0296 \pm 0.0107$ & $2.4876 \pm 0.2907$ & $0.0000 \pm 0.063$ & $0.0000 \pm 0.2916$ & $0.0000 \pm 0.078$ \\
\hline $\mathrm{Ti}$ & $0.0000 \pm 0.0007$ & $0.0013 \pm 0.0006$ & $0.0150 \pm 0.003$ & $0.0084 \pm 0.0037$ & $0.0104 \pm 0.0136$ & $0.0000 \pm 0.0041$ \\
\hline $\mathrm{V}$ & $0.0059 \pm 0.0077$ & $0.0000 \pm 0.0004$ & $0.0000 \pm 0.0001$ & $0.0009 \pm 0.0031$ & $0.0000 \pm 0.0003$ & $0.0004 \pm 0.0035$ \\
\hline $\mathrm{Cr}$ & $0.0135 \pm 0.0162$ & $0.0009 \pm 0.001$ & $0.0034 \pm 0.0023$ & $0.0053 \pm 0.0059$ & $0.0236 \pm 0.0235$ & $0.0094 \pm 0.0074$ \\
\hline Mn & $0.0183 \pm 0.0137$ & $0.0008 \pm 0.0008$ & $0.0000 \pm 0.0021$ & $0.0021 \pm 0.005$ & $0.0000 \pm 0.0009$ & $0.0000 \pm 0.0002$ \\
\hline $\mathrm{Fe}$ & $0.0000 \pm 0.0082$ & $0.0069 \pm 0.0022$ & $0.1781 \pm 0.0288$ & $0.0353 \pm 0.0162$ & $0.0308 \pm 0.0678$ & $0.0013 \pm 0.0181$ \\
\hline $\mathrm{Co}$ & $0.0017 \pm 0.0068$ & $0.0000 \pm 0.0003$ & $0.0000 \pm 0.0002$ & $0.0000 \pm 0.0001$ & $0.0000 \pm 0.0004$ & $0.0042 \pm 0.0031$ \\
\hline $\mathrm{Ni}$ & $0.0000 \pm 0.0005$ & $0.0000 \pm 0.0003$ & $0.0007 \pm 0.0009$ & $0.0000 \pm 0.0019$ & $0.0000 \pm 0.0081$ & $0.0019 \pm 0.0027$ \\
\hline $\mathrm{Cu}$ & $0.0262 \pm 0.0081$ & $0.0035 \pm 0.0006$ & $0.0033 \pm 0.0013$ & $0.0108 \pm 0.0032$ & $0.0000 \pm 0.0003$ & $0.0019 \pm 0.0035$ \\
\hline $\mathrm{Zn}$ & $0.0099 \pm 0.0077$ & $0.0044 \pm 0.0006$ & $0.0388 \pm 0.0038$ & $0.0637 \pm 0.0068$ & $0.0000 \pm 0.0009$ & $0.0046 \pm 0.0035$ \\
\hline $\mathrm{Ga}$ & $0.0000 \pm 0.0059$ & $0.0000 \pm 0.0003$ & $0.0000 \pm 0.0001$ & $0.0012 \pm 0.0025$ & $0.0000 \pm 0.0002$ & $0.0027 \pm 0.0031$ \\
\hline $\mathrm{Ge}$ & $0.0025 \pm 0.0068$ & $0.0004 \pm 0.0004$ & $0.0004 \pm 0.001$ & $0.0012 \pm 0.0028$ & $0.0000 \pm 0.0002$ & $0.0000 \pm 0.0001$ \\
\hline As & $0.0000 \pm 0.0077$ & $0.0000 \pm 0.0006$ & $0.0000 \pm 0.0001$ & $0.0000 \pm 0.0001$ & $0.0000 \pm 0.0003$ & $0.0011 \pm 0.0054$ \\
\hline $\mathrm{Se}$ & $0.0000 \pm 0.0068$ & $0.0000 \pm 0.0004$ & $0.0000 \pm 0.0001$ & $0.0009 \pm 0.0031$ & $0.006 \pm 0.0123$ & $0.0000 \pm 0.0001$ \\
\hline $\mathrm{Br}$ & $0.0068 \pm 0.0085$ & $0.0279 \pm 0.0026$ & $0.0534 \pm 0.0051$ & $0.2374 \pm 0.0226$ & $0.0451 \pm 0.0147$ & $0.0404 \pm 0.006$ \\
\hline $\mathrm{Rb}$ & $0.0000 \pm 0.0068$ & $0.0011 \pm 0.0007$ & $0.0032 \pm 0.0016$ & $0.0059 \pm 0.0044$ & $0.0000 \pm 0.0003$ & $0.0000 \pm 0.0001$ \\
\hline $\mathrm{Sr}$ & $0.0000 \pm 0.0002$ & $0.0015 \pm 0.0007$ & $0.0105 \pm 0.0023$ & $0.0061 \pm 0.0044$ & $0.0036 \pm 0.0172$ & $0.0014 \pm 0.0055$ \\
\hline $\mathrm{Y}$ & $0.0000 \pm 0.0119$ & $0.0000 \pm 0.001$ & $0.0000 \pm 0.0001$ & $0.0000 \pm 0.0001$ & $0.0000 \pm 0.0002$ & $0.0000 \pm 0.0001$ \\
\hline $\mathrm{Zr}$ & $0.0118 \pm 0.0221$ & $0.0000 \pm 0.001$ & $0.0007 \pm 0.0032$ & $0.0000 \pm 0.0001$ & $0.0085 \pm 0.0307$ & $0.0000 \pm 0.0001$ \\
\hline Mo & $0.0196 \pm 0.0281$ & $0.0000 \pm 0.0016$ & $0.0026 \pm 0.0041$ & $0.0003 \pm 0.0012$ & $0.0184 \pm 0.0406$ & $0.0000 \pm 0.0129$ \\
\hline $\mathrm{Pd}$ & $0.0314 \pm 0.0181$ & $0.0013 \pm 0.001$ & $0.0000 \pm 0.0003$ & $0.0105 \pm 0.0066$ & $0.0000 \pm 0.0007$ & $0.0000 \pm 0.0002$ \\
\hline $\mathrm{Ag}$ & $0.0000 \pm 0.0001$ & $0.0000 \pm 0.0013$ & $0.0067 \pm 0.0026$ & $0.0032 \pm 0.0062$ & $0.0000 \pm 0.0006$ & $0.0000 \pm 0.0002$ \\
\hline $\mathrm{Cd}$ & $0.0000 \pm 0.0001$ & $0.0000 \pm 0.0014$ & $0.0000 \pm 0.0003$ & $0.0154 \pm 0.0091$ & $0.0000 \pm 0.0006$ & $0.0000 \pm 0.0002$ \\
\hline In & $0.0153 \pm 0.0264$ & $0.0023 \pm 0.0015$ & $0.001 \pm 0.0038$ & $0.0000 \pm 0.0096$ & $0.0000 \pm 0.0381$ & $0.0000 \pm 0.0121$ \\
\hline $\mathrm{Sn}$ & $0.0212 \pm 0.0307$ & $0.0055 \pm 0.0018$ & $0.0213 \pm 0.0048$ & $0.0000 \pm 0.0002$ & $0.104 \pm 0.0474$ & $0.072 \pm 0.0159$ \\
\hline $\mathrm{Sb}$ & $0.0000 \pm 0.0055$ & $0.0000 \pm 0.0031$ & $0.0000 \pm 0.0079$ & $0.0143 \pm 0.0201$ & $0.0000 \pm 0.0565$ & $0.0023 \pm 0.0179$ \\
\hline $\mathrm{Ba}$ & $0.0000 \pm 0.0001$ & $0.0000 \pm 0.0021$ & $0.0082 \pm 0.0079$ & $0.003 \pm 0.0167$ & $0.0000 \pm 0.0011$ & $0.0000 \pm 0.0003$ \\
\hline $\mathrm{La}$ & $0.0136 \pm 0.0264$ & $0.0000 \pm 0.0013$ & $0.0000 \pm 0.0033$ & $0.0012 \pm 0.0105$ & $0.0000 \pm 0.0332$ & $0.0000 \pm 0.0105$ \\
\hline $\mathrm{Hg}$ & $0.0136 \pm 0.0145$ & $0.0009 \pm 0.0009$ & $0.0000 \pm 0.0015$ & $0.005 \pm 0.0056$ & $0.016 \pm 0.0198$ & $0.0000 \pm 0.0047$ \\
\hline $\mathrm{Pb}$ & $0.0000 \pm 0.0001$ & $0.0000 \pm 0.0006$ & $0.0104 \pm 0.0023$ & $0.0052 \pm 0.0065$ & $0.0182 \pm 0.0247$ & $0.0065 \pm 0.0082$ \\
\hline $\mathrm{EC}$ & $4.3344 \pm 0.5326$ & $0.3531 \pm 0.0316$ & $0.1432 \pm 0.0366$ & $0.3056 \pm 0.0801$ & $1.4332 \pm 0.3245$ & $4.3119 \pm 0.3909$ \\
\hline $\mathrm{OC}$ & $85.653 \pm 8.9266$ & $25.6443 \pm 1.8299$ & $2.0984 \pm 0.1831$ & $17.7176 \pm 1.4086$ & $72.6909 \pm 9.603$ & $98.9575 \pm 7.853$ \\
\hline
\end{tabular}


TABLE SIII. PROFILES FOR INDUSTRY EMISSIONS (PERCENT MASS).

\begin{tabular}{|c|c|c|c|c|c|c|}
\hline & \multicolumn{2}{|c|}{ Oil refinery } & \multicolumn{4}{|c|}{ Industrial park } \\
\hline & PMX1 & PMX2 & PSN1 & PSN2 & PSN3 & PSN4 \\
\hline $\mathrm{Na}$ & $2.5011 \pm 1.1913$ & $0.9761 \pm 0.6802$ & $0.0000 \pm 1.0118$ & $0.4559 \pm 0.7561$ & $0.8537 \pm 0.5981$ & $0.7989 \pm 0.8113$ \\
\hline $\mathrm{Mg}$ & $0.5411 \pm 0.6021$ & $0.1584 \pm 0.3569$ & $0.0000 \pm 0.0528$ & $0.8689 \pm 0.3583$ & $0.531 \pm 0.2608$ & $0.0000 \pm 0.3165$ \\
\hline $\mathrm{Al}$ & $0.9423 \pm 1.4821$ & $0.7441 \pm 0.8641$ & $0.2207 \pm 0.3613$ & $0.3413 \pm 0.2527$ & $0.1923 \pm 0.2305$ & $0.2044 \pm 0.2186$ \\
\hline $\mathrm{Si}$ & $0.0000 \pm 3.2454$ & $0.0000 \pm 1.8959$ & $0.0000 \pm 0.6602$ & $0.0000 \pm 0.3974$ & $0.0000 \pm 0.4456$ & $0.0000 \pm 0.3234$ \\
\hline $\mathrm{P}$ & $0.0000 \pm 0.0691$ & $0.0047 \pm 0.0475$ & $0.0747 \pm 0.066$ & $0.0091 \pm 0.0476$ & $0.0595 \pm 0.0409$ & $0.0000 \pm 0.0495$ \\
\hline S & $5.4594 \pm 1.3748$ & $3.6478 \pm 0.6446$ & $8.6265 \pm 2.1118$ & $7.9674 \pm 1.5068$ & $13.792 \pm 2.126$ & $11.856 \pm 2.3296$ \\
\hline $\mathrm{Cl}$ & $0.6500 \pm 0.1937$ & $0.2680 \pm 0.0809$ & $0.2109 \pm 0.1104$ & $0.1656 \pm 0.0812$ & $0.1822 \pm 0.0633$ & $0.4414 \pm 0.117$ \\
\hline K & $0.6991 \pm 0.6437$ & $0.0000 \pm 0.2700$ & $0.4952 \pm 0.2107$ & $0.3251 \pm 0.1177$ & $0.1386 \pm 0.0889$ & $0.1744 \pm 0.0839$ \\
\hline $\mathrm{Ca}$ & $0.0000 \pm 3.3475$ & $0.0000 \pm 2.0082$ & $0.0000 \pm 0.7042$ & $0.0000 \pm 0.4844$ & $0.3027 \pm 0.6491$ & $0.0000 \pm 0.3742$ \\
\hline $\mathrm{Ti}$ & $0.1121 \pm 0.0897$ & $0.112 \pm 0.0546$ & $0.0000 \pm 0.026$ & $0.0166 \pm 0.0212$ & $0.005 \pm 0.0169$ & $0.0391 \pm 0.0234$ \\
\hline $\mathrm{V}$ & $0.0000 \pm 0.0031$ & $0.0000 \pm 0.0021$ & $0.0106 \pm 0.0235$ & $0.0000 \pm 0.0004$ & $0.0283 \pm 0.0138$ & $0.0207 \pm 0.0183$ \\
\hline $\mathrm{Cr}$ & $0.0051 \pm 0.0486$ & $0.0445 \pm 0.0324$ & $0.1035 \pm 0.0549$ & $0.0552 \pm 0.0374$ & $0.1085 \pm 0.0314$ & $0.1162 \pm 0.0454$ \\
\hline $\mathrm{Mn}$ & $0.0536 \pm 0.0478$ & $0.0000 \pm 0.0061$ & $0.0257 \pm 0.0416$ & $0.0188 \pm 0.0304$ & $0.0023 \pm 0.0216$ & $0.1108 \pm 0.0402$ \\
\hline $\mathrm{Fe}$ & $0.0000 \pm 0.7186$ & $0.1153 \pm 0.4373$ & $0.2208 \pm 0.1994$ & $0.1106 \pm 0.1135$ & $0.0700 \pm 0.1120$ & $0.2926 \pm 0.1271$ \\
\hline Co & $0.0000 \pm 0.003$ & $0.0000 \pm 0.0024$ & $0.0000 \pm 0.0006$ & $0.0000 \pm 0.0004$ & $0.0008 \pm 0.0114$ & $0.0075 \pm 0.016$ \\
\hline $\mathrm{Ni}$ & $0.0000 \pm 0.0185$ & $0.0032 \pm 0.0116$ & $0.0025 \pm 0.0183$ & $0.0017 \pm 0.0133$ & $0.0000 \pm 0.0101$ & $0.0000 \pm 0.014$ \\
\hline $\mathrm{Cu}$ & $0.0268 \pm 0.025$ & $0.0172 \pm 0.0155$ & $0.0644 \pm 0.028$ & $0.0267 \pm 0.0179$ & $0.0394 \pm 0.0143$ & $0.1139 \pm 0.0294$ \\
\hline $\mathrm{Zn}$ & $0.0044 \pm 0.027$ & $0.0000 \pm 0.016$ & $0.0185 \pm 0.0242$ & $0.1337 \pm 0.0316$ & $0.0583 \pm 0.016$ & $0.0316 \pm 0.0191$ \\
\hline $\mathrm{Ga}$ & $0.0000 \pm 0.0014$ & $0.0051 \pm 0.0129$ & $0.023 \pm 0.0215$ & $0.0000 \pm 0.0002$ & $0.0000 \pm 0.0003$ & $0.0177 \pm 0.0163$ \\
\hline $\mathrm{Ge}$ & $0.0000 \pm 0.0014$ & $0.0000 \pm 0.0011$ & $0.0022 \pm 0.0208$ & $0.0148 \pm 0.0153$ & $0.001 \pm 0.0114$ & $0.0037 \pm 0.016$ \\
\hline As & $0.0000 \pm 0.0021$ & $0.0000 \pm 0.0017$ & $0.0538 \pm 0.0427$ & $0.013 \pm 0.0323$ & $0.0123 \pm 0.0202$ & $0.0472 \pm 0.0368$ \\
\hline $\mathrm{Se}$ & $0.0009 \pm 0.0254$ & $0.0000 \pm 0.0011$ & $0.0072 \pm 0.0259$ & $0.0000 \pm 0.0002$ & $0.0028 \pm 0.0145$ & $0.0057 \pm 0.0199$ \\
\hline $\mathrm{Br}$ & $0.0000 \pm 0.0012$ & $0.0062 \pm 0.0148$ & $0.0303 \pm 0.0244$ & $0.0052 \pm 0.0189$ & $0.0153 \pm 0.0129$ & $0.0254 \pm 0.0185$ \\
\hline $\mathrm{Rb}$ & $0.0000 \pm 0.0026$ & $0.0000 \pm 0.0181$ & $0.0000 \pm 0.0005$ & $0.0000 \pm 0.0003$ & $0.0039 \pm 0.0145$ & $0.0000 \pm 0.0003$ \\
\hline $\mathrm{Sr}$ & $0.0000 \pm 0.0351$ & $0.0000 \pm 0.0244$ & $0.028 \pm 0.0369$ & $0.0000 \pm 0.0262$ & $0.0034 \pm 0.0185$ & $0.0000 \pm 0.001$ \\
\hline $\mathrm{Y}$ & $0.0000 \pm 0.0018$ & $0.0000 \pm 0.0015$ & $0.0000 \pm 0.0004$ & $0.0000 \pm 0.0003$ & $0.0086 \pm 0.0259$ & $0.0000 \pm 0.0002$ \\
\hline $\mathrm{Zr}$ & $0.0079 \pm 0.0648$ & $0.0126 \pm 0.0425$ & $0.0029 \pm 0.0667$ & $0.0663 \pm 0.0504$ & $0.0036 \pm 0.036$ & $0.0000 \pm 0.0004$ \\
\hline Mo & $0.0000 \pm 0.0842$ & $0.0116 \pm 0.0539$ & $0.0592 \pm 0.0861$ & $0.0189 \pm 0.0624$ & $0.0000 \pm 0.0474$ & $0.0319 \pm 0.0656$ \\
\hline $\mathrm{Pd}$ & $0.0184 \pm 0.0524$ & $0.0000 \pm 0.0043$ & $0.1408 \pm 0.0633$ & $0.0000 \pm 0.0008$ & $0.0000 \pm 0.0011$ & $0.0198 \pm 0.0398$ \\
\hline $\mathrm{Ag}$ & $0.0000 \pm 0.0051$ & $0.0000 \pm 0.004$ & $0.0000 \pm 0.001$ & $0.0251 \pm 0.0381$ & $0.0072 \pm 0.0285$ & $0.0151 \pm 0.0398$ \\
\hline $\mathrm{Cd}$ & $0.0000 \pm 0.0054$ & $0.0553 \pm 0.0363$ & $0.0000 \pm 0.0011$ & $0.0000 \pm 0.0008$ & $0.0263 \pm 0.0305$ & $0.0000 \pm 0.0006$ \\
\hline In & $0.0000 \pm 0.0797$ & $0.0000 \pm 0.0208$ & $0.0975 \pm 0.08$ & $0.0000 \pm 0.0584$ & $0.0114 \pm 0.0443$ & $0.135 \pm 0.0684$ \\
\hline $\mathrm{Sn}$ & $0.0000 \pm 0.006$ & $0.0000 \pm 0.0048$ & $0.0000 \pm 0.0012$ & $0.0000 \pm 0.0009$ & $0.0354 \pm 0.052$ & $0.1879 \pm 0.0815$ \\
\hline $\mathrm{Sb}$ & $0.195 \pm 0.1294$ & $0.0000 \pm 0.1065$ & $0.0000 \pm 0.1668$ & $0.0000 \pm 0.1225$ & $0.1232 \pm 0.0696$ & $0.0000 \pm 0.091$ \\
\hline $\mathrm{Ba}$ & $0.0000 \pm 0.0094$ & $0.0000 \pm 0.0069$ & $0.0000 \pm 0.0019$ & $0.0101 \pm 0.0774$ & $0.0000 \pm 0.0017$ & $0.0000 \pm 0.001$ \\
\hline $\mathrm{La}$ & $0.0000 \pm 0.0693$ & $0.0000 \pm 0.0443$ & $0.0000 \pm 0.0692$ & $0.0000 \pm 0.0507$ & $0.0000 \pm 0.0456$ & $0.0039 \pm 0.0576$ \\
\hline $\mathrm{Hg}$ & $0.0542 \pm 0.0434$ & $0.0000 \pm 0.0199$ & $0.0000 \pm 0.0308$ & $0.0000 \pm 0.0301$ & $0.0000 \pm 0.0171$ & $0.0058 \pm 0.0319$ \\
\hline $\mathrm{Pb}$ & $0.0091 \pm 0.042$ & $0.0000 \pm 0.003$ & $0.016 \pm 0.0543$ & $0.1246 \pm 0.049$ & $0.002 \pm 0.0272$ & $0.183 \pm 0.0575$ \\
\hline $\mathrm{EC}$ & $3.3086 \pm 1.4265$ & $1.1600 \pm 0.6974$ & $1.6367 \pm 0.9204$ & $2.1258 \pm 0.5706$ & $2.1616 \pm 0.5324$ & $1.1497 \pm 0.4442$ \\
\hline $\mathrm{OC}$ & $28.986 \pm 8.2109$ & $17.556 \pm 3.5711$ & $31.6182 \pm 7.9694$ & $20.3919 \pm 3.8869$ & $21.8966 \pm 3.3749$ & $20.5 \pm 4.1375$ \\
\hline
\end{tabular}


TABLE SIV. PROFILES FOR BIOMASS BURNING AND FUGITIVE DUST EMISSIONS (PERCENT MASS).

\begin{tabular}{|c|c|c|c|c|}
\hline & \multicolumn{2}{|c|}{ Open-waste burning } & \multicolumn{2}{|c|}{ Urban construction } \\
\hline & QB1 & QB2 & RP1 & RP2 \\
\hline $\mathrm{Na}$ & $0.2370 \pm 0.3022$ & $0.251 \pm 0.4182$ & $0.0310 \pm 0.0388$ & $0.0084 \pm 0.0152$ \\
\hline $\mathrm{Mg}$ & $0.1434 \pm 0.1214$ & $0.0488 \pm 0.1679$ & $0.0075 \pm 0.0212$ & $0.0104 \pm 0.0070$ \\
\hline $\mathrm{Al}$ & $0.0733 \pm 0.0669$ & $0.0154 \pm 0.0913$ & $0.0735 \pm 0.0426$ & $0.0366 \pm 0.0142$ \\
\hline $\mathrm{Si}$ & $0.0000 \pm 0.0701$ & $0.0000 \pm 0.1059$ & $0.0676 \pm 0.0399$ & $0.0217 \pm 0.0124$ \\
\hline $\mathrm{P}$ & $0.0000 \pm 0.0007$ & $0.0000 \pm 0.0239$ & $0.1984 \pm 0.3574$ & $0.1963 \pm 0.1604$ \\
\hline $\mathrm{S}$ & $0.3886 \pm 0.0504$ & $0.5108 \pm 0.0759$ & $0.0000 \pm 0.0016$ & $0.0000 \pm 0.0012$ \\
\hline $\mathrm{Cl}$ & $0.9643 \pm 0.1131$ & $1.3548 \pm 0.1839$ & $0.0125 \pm 0.0148$ & $0.0014 \pm 0.0048$ \\
\hline $\mathrm{K}$ & $1.4204 \pm 0.1639$ & $1.7229 \pm 0.2352$ & $0.0129 \pm 0.0193$ & $0.0000 \pm 0.0010$ \\
\hline $\mathrm{Ca}$ & $0.0000 \pm 0.0848$ & $0.0000 \pm 0.1221$ & $0.1877 \pm 0.0472$ & $0.0340 \pm 0.0086$ \\
\hline $\mathrm{Ti}$ & $0.0107 \pm 0.0081$ & $0.0016 \pm 0.0111$ & $0.0033 \pm 0.0146$ & $0.0000 \pm 0.0006$ \\
\hline $\mathrm{V}$ & $0.0000 \pm 0.0001$ & $0.0006 \pm 0.0098$ & $0.0000 \pm 0.0008$ & $0.0000 \pm 0.0006$ \\
\hline $\mathrm{Cr}$ & $0.0000 \pm 0.0001$ & $0.054 \pm 0.0216$ & $0.0242 \pm 0.0318$ & $0.0000 \pm 0.0008$ \\
\hline $\mathrm{Mn}$ & $0.0035 \pm 0.0118$ & $0.0000 \pm 0.0003$ & $0.0000 \pm 0.0008$ & $0.0000 \pm 0.0006$ \\
\hline $\mathrm{Fe}$ & $0.0056 \pm 0.0245$ & $0.0242 \pm 0.037$ & $0.0000 \pm 0.0007$ & $0.0000 \pm 0.0005$ \\
\hline $\mathrm{Co}$ & $0.0015 \pm 0.0063$ & $0.0000 \pm 0.0001$ & $0.0000 \pm 0.0013$ & $0.0000 \pm 0.0008$ \\
\hline $\mathrm{Ni}$ & $0.0000 \pm 0.0047$ & $0.0000 \pm 0.0076$ & $0.0003 \pm 0.0300$ & $0.0000 \pm 0.0099$ \\
\hline $\mathrm{Cu}$ & $0.0098 \pm 0.0071$ & $0.0267 \pm 0.0103$ & $0.0016 \pm 0.0398$ & $0.0140 \pm 0.0131$ \\
\hline $\mathrm{Zn}$ & $0.0577 \pm 0.0098$ & $0.1906 \pm 0.0271$ & $0.0000 \pm 0.0544$ & $0.0155 \pm 0.0173$ \\
\hline $\mathrm{Ga}$ & $0.0000 \pm 0.0055$ & $0.0000 \pm 0.0001$ & $0.0000 \pm 0.0007$ & $0.0185 \pm 0.0227$ \\
\hline $\mathrm{Ge}$ & $0.0007 \pm 0.0063$ & $0.0032 \pm 0.0087$ & $0.0000 \pm 0.0028$ & $0.0000 \pm 0.0022$ \\
\hline As & $0.0243 \pm 0.012$ & $0.0000 \pm 0.0001$ & $0.0000 \pm 0.0027$ & $0.0000 \pm 0.0020$ \\
\hline $\mathrm{Se}$ & $0.0000 \pm 0.0063$ & $0.0108 \pm 0.011$ & $0.0000 \pm 0.0028$ & $0.0000 \pm 0.0020$ \\
\hline $\mathrm{Br}$ & $0.12 \pm 0.0167$ & $0.0433 \pm 0.013$ & $0.0000 \pm 0.0006$ & $0.0000 \pm 0.0002$ \\
\hline $\mathrm{Rb}$ & $0.0000 \pm 0.0001$ & $0.0072 \pm 0.012$ & $0.0508 \pm 0.0761$ & $0.0502 \pm 0.0259$ \\
\hline $\mathrm{Sr}$ & $0.0042 \pm 0.0102$ & $0.0015 \pm 0.0141$ & $0.2845 \pm 0.1133$ & $0.0383 \pm 0.0324$ \\
\hline $\mathrm{Y}$ & $0.0015 \pm 0.0141$ & $0.0108 \pm 0.0207$ & $0.0000 \pm 0.0047$ & $0.0000 \pm 0.0033$ \\
\hline $\mathrm{Zr}$ & $0.0000 \pm 0.0001$ & $0.0006 \pm 0.0272$ & $0.0000 \pm 0.0006$ & $0.0000 \pm 0.0002$ \\
\hline Mo & $0.0000 \pm 0.0259$ & $0.0000 \pm 0.0359$ & $0.0125 \pm 0.0336$ & $0.0123 \pm 0.0110$ \\
\hline $\mathrm{Pd}$ & $0.0000 \pm 0.0002$ & $0.0196 \pm 0.0219$ & $0.0482 \pm 0.0453$ & $0.0267 \pm 0.0121$ \\
\hline $\mathrm{Ag}$ & $0.0000 \pm 0.0002$ & $0.0000 \pm 0.0002$ & $7.8115 \pm 1.6908$ & $3.3482 \pm 0.4077$ \\
\hline $\mathrm{Cd}$ & $0.0263 \pm 0.0167$ & $0.0201 \pm 0.0229$ & $21.3377 \pm 4.8579$ & $10.0489 \pm 1.2212$ \\
\hline In & $0.0298 \pm 0.0245$ & $0.0000 \pm 0.0338$ & $0.0310 \pm 0.0388$ & $0.0084 \pm 0.0152$ \\
\hline $\mathrm{Sn}$ & $0.0000 \pm 0.0002$ & $0.1357 \pm 0.0434$ & $0.0075 \pm 0.0212$ & $0.0104 \pm 0.0070$ \\
\hline $\mathrm{Sb}$ & $0.0000 \pm 0.0361$ & $0.0717 \pm 0.0518$ & $0.0735 \pm 0.0426$ & $0.0366 \pm 0.0142$ \\
\hline $\mathrm{Ba}$ & $0.0213 \pm 0.0385$ & $0.0218 \pm 0.0533$ & $0.0676 \pm 0.0399$ & $0.0217 \pm 0.0124$ \\
\hline $\mathrm{La}$ & $0.0173 \pm 0.0252$ & $0.0043 \pm 0.0348$ & $0.1984 \pm 0.3574$ & $0.1963 \pm 0.1604$ \\
\hline $\mathrm{Hg}$ & $0.0039 \pm 0.0134$ & $0.013 \pm 0.0174$ & $0.0000 \pm 0.0016$ & $0.0000 \pm 0.0012$ \\
\hline $\mathrm{Pb}$ & $0.0051 \pm 0.0165$ & $0.0723 \pm 0.0204$ & $0.0125 \pm 0.0148$ & $0.0014 \pm 0.0048$ \\
\hline $\mathrm{EC}$ & $43.8549 \pm 4.4064$ & $48.9667 \pm 5.9522$ & $0.0129 \pm 0.0193$ & $0.0000 \pm 0.0010$ \\
\hline $\mathrm{OC}$ & $50.572 \pm 5.0956$ & $52.1948 \pm 6.3624$ & $0.1877 \pm 0.0472$ & $0.0340 \pm 0.0086$ \\
\hline
\end{tabular}


TABLE SV. PROFILES FOR NATURAL EMISSIONS (PERCENT MASS).

\begin{tabular}{|c|c|c|c|c|c|}
\hline & \multicolumn{3}{|c|}{ Vegetative detritus (daytime) } & \multicolumn{2}{|c|}{ Vegetative detritus (nighttime) } \\
\hline & RT1 & RT3 & RT4 & RT2 & RT5 \\
\hline $\mathrm{Na}$ & $0.8134 \pm 0.5512$ & $0.9559 \pm 0.5516$ & $0.5409 \pm 0.3355$ & $0.6369 \pm 0.6178$ & $0.6993 \pm 0.3306$ \\
\hline $\mathrm{Mg}$ & $0.5539 \pm 0.235$ & $0.4287 \pm 0.2477$ & $0.1484 \pm 0.1354$ & $0.255 \pm 0.2519$ & $0.1432 \pm 0.1334$ \\
\hline $\mathrm{Al}$ & $0.4151 \pm 0.1848$ & $0.378 \pm 0.3044$ & $0.1421 \pm 0.0865$ & $0.2333 \pm 0.2489$ & $0.1188 \pm 0.0989$ \\
\hline $\mathrm{Si}$ & $0.0000 \pm 0.2663$ & $0.0000 \pm 0.6098$ & $0.0000 \pm 0.1206$ & $0.0000 \pm 0.4793$ & $0.0000 \pm 0.167$ \\
\hline $\mathrm{P}$ & $0.0000 \pm 0.0327$ & $0.0000 \pm 0.0357$ & $0.026 \pm 0.0222$ & $0.0367 \pm 0.0408$ & $0.001 \pm 0.0234$ \\
\hline $\mathrm{S}$ & $6.8343 \pm 0.9991$ & $8.8332 \pm 1.2825$ & $10.6421 \pm 1.1844$ & $11.2609 \pm 1.7693$ & $13.0784 \pm 1.4201$ \\
\hline $\mathrm{Cl}$ & $2.2293 \pm 0.3317$ & $0.1434 \pm 0.0569$ & $0.0498 \pm 0.0324$ & $0.2426 \pm 0.0705$ & $0.0376 \pm 0.0316$ \\
\hline K & $0.172 \pm 0.0645$ & $0.175 \pm 0.1158$ & $0.1017 \pm 0.0296$ & $0.2008 \pm 0.1021$ & $0.2329 \pm 0.0479$ \\
\hline $\mathrm{Ca}$ & $0.0000 \pm 0.291$ & $0.0000 \pm 0.6489$ & $0.0000 \pm 0.1344$ & $0.0000 \pm 0.5119$ & $0.0000 \pm 0.1858$ \\
\hline $\mathrm{Ti}$ & $0.0174 \pm 0.0145$ & $0.0272 \pm 0.0191$ & $0.0077 \pm 0.0083$ & $0.0197 \pm 0.0185$ & $0.008 \pm 0.0081$ \\
\hline $\mathrm{V}$ & $0.0107 \pm 0.0119$ & $0.0193 \pm 0.0135$ & $0.0157 \pm 0.008$ & $0.0038 \pm 0.0148$ & $0.0179 \pm 0.0076$ \\
\hline $\mathrm{Cr}$ & $0.0388 \pm 0.0254$ & $0.0457 \pm 0.0256$ & $0.0331 \pm 0.0151$ & $0.0674 \pm 0.031$ & $0.0414 \pm 0.0152$ \\
\hline $\mathrm{Mn}$ & $0.0178 \pm 0.0215$ & $0.0000 \pm 0.002$ & $0.0278 \pm 0.0129$ & $0.0417 \pm 0.0262$ & $0.0136 \pm 0.0127$ \\
\hline $\mathrm{Fe}$ & $0.041 \pm 0.0709$ & $0.0332 \pm 0.142$ & $0.1515 \pm 0.0433$ & $0.0071 \pm 0.1132$ & $0.0616 \pm 0.0449$ \\
\hline $\mathrm{Co}$ & $0.0000 \pm 0.0004$ & $0.0000 \pm 0.0009$ & $0.0000 \pm 0.0002$ & $0.0000 \pm 0.0006$ & $0.0034 \pm 0.0059$ \\
\hline $\mathrm{Ni}$ & $0.0012 \pm 0.0095$ & $0.009 \pm 0.0091$ & $0.0000 \pm 0.0055$ & $0.0000 \pm 0.0101$ & $0.0000 \pm 0.0044$ \\
\hline $\mathrm{Cu}$ & $0.1088 \pm 0.0208$ & $0.0812 \pm 0.0174$ & $0.0102 \pm 0.0072$ & $0.2999 \pm 0.0499$ & $0.0274 \pm 0.0078$ \\
\hline $\mathrm{Zn}$ & $0.044 \pm 0.0134$ & $0.0000 \pm 0.0119$ & $0.0452 \pm 0.0092$ & $0.0126 \pm 0.0135$ & $0.0234 \pm 0.007$ \\
\hline $\mathrm{Ga}$ & $0.0000 \pm 0.0002$ & $0.0007 \pm 0.009$ & $0.0000 \pm 0.0001$ & $0.0000 \pm 0.0003$ & $0.0000 \pm 0.0001$ \\
\hline $\mathrm{Ge}$ & $0.0039 \pm 0.0107$ & $0.0000 \pm 0.0004$ & $0.0015 \pm 0.0063$ & $0.0127 \pm 0.0119$ & $0.0000 \pm 0.0001$ \\
\hline As & $0.0000 \pm 0.0002$ & $0.0000 \pm 0.0006$ & $0.0092 \pm 0.0118$ & $0.0025 \pm 0.0206$ & $0.0142 \pm 0.0112$ \\
\hline $\mathrm{Se}$ & $0.0075 \pm 0.0131$ & $0.0000 \pm 0.0004$ & $0.0015 \pm 0.0077$ & $0.0000 \pm 0.0003$ & $0.0058 \pm 0.0074$ \\
\hline $\mathrm{Br}$ & $0.0062 \pm 0.0119$ & $0.0000 \pm 0.0003$ & $0.0029 \pm 0.0069$ & $0.0000 \pm 0.0002$ & $0.0149 \pm 0.0075$ \\
\hline $\mathrm{Rb}$ & $0.0001 \pm 0.0142$ & $0.0000 \pm 0.0006$ & $0.0000 \pm 0.0001$ & $0.0000 \pm 0.0005$ & $0.0036 \pm 0.0082$ \\
\hline $\mathrm{Sr}$ & $0.0000 \pm 0.0009$ & $0.0027 \pm 0.0185$ & $0.0037 \pm 0.0102$ & $0.0000 \pm 0.0207$ & $0.0000 \pm 0.0006$ \\
\hline $\mathrm{Y}$ & $0.0000 \pm 0.0002$ & $0.0000 \pm 0.0005$ & $0.0000 \pm 0.0001$ & $0.0000 \pm 0.0004$ & $0.011 \pm 0.0137$ \\
\hline $\mathrm{Zr}$ & $0.0000 \pm 0.0003$ & $0.0000 \pm 0.0008$ & $0.0000 \pm 0.0002$ & $0.0197 \pm 0.0368$ & $0.0000 \pm 0.0003$ \\
\hline Mo & $0.0184 \pm 0.0433$ & $0.0078 \pm 0.0429$ & $0.0000 \pm 0.0256$ & $0.0733 \pm 0.0495$ & $0.0000 \pm 0.0241$ \\
\hline $\mathrm{Pd}$ & $0.0000 \pm 0.0006$ & $0.0000 \pm 0.0016$ & $0.0281 \pm 0.0166$ & $0.0000 \pm 0.0011$ & $0.0000 \pm 0.0005$ \\
\hline $\mathrm{Ag}$ & $0.0000 \pm 0.0006$ & $0.0000 \pm 0.0014$ & $0.0526 \pm 0.0172$ & $0.0000 \pm 0.0011$ & $0.084 \pm 0.0174$ \\
\hline $\mathrm{Cd}$ & $0.0000 \pm 0.0006$ & $0.0000 \pm 0.0015$ & $0.0524 \pm 0.0172$ & $0.0107 \pm 0.0426$ & $0.0000 \pm 0.0005$ \\
\hline In & $0.0764 \pm 0.042$ & $0.1274 \pm 0.042$ & $0.0000 \pm 0.0242$ & $0.0000 \pm 0.0455$ & $0.0059 \pm 0.0226$ \\
\hline $\mathrm{Sn}$ & $0.0000 \pm 0.0007$ & $0.0186 \pm 0.0468$ & $0.0114 \pm 0.0281$ & $0.1976 \pm 0.0618$ & $0.0000 \pm 0.0006$ \\
\hline $\mathrm{Sb}$ & $0.0865 \pm 0.0626$ & $0.0000 \pm 0.0596$ & $0.0000 \pm 0.0358$ & $0.0000 \pm 0.0651$ & $0.0000 \pm 0.0474$ \\
\hline $\mathrm{Ba}$ & $0.0000 \pm 0.001$ & $0.0000 \pm 0.0558$ & $0.0702 \pm 0.0397$ & $0.0000 \pm 0.0018$ & $0.0556 \pm 0.0384$ \\
\hline $\mathrm{La}$ & $0.0000 \pm 0.0355$ & $0.0000 \pm 0.0351$ & $0.0336 \pm 0.026$ & $0.0000 \pm 0.0383$ & $0.0263 \pm 0.0249$ \\
\hline $\mathrm{Hg}$ & $0.0000 \pm 0.0159$ & $0.0117 \pm 0.0222$ & $0.0016 \pm 0.0124$ & $0.0000 \pm 0.0242$ & $0.0015 \pm 0.0122$ \\
\hline $\mathrm{Pb}$ & $0.0169 \pm 0.0215$ & $0.0000 \pm 0.001$ & $0.0062 \pm 0.0163$ & $0.0122 \pm 0.0295$ & $0.0000 \pm 0.0003$ \\
\hline $\mathrm{EC}$ & $1.1661 \pm 0.6118$ & $1.1536 \pm 0.3422$ & $0.7966 \pm 0.176$ & $3.893 \pm 0.6388$ & $2.2053 \pm 0.4126$ \\
\hline $\mathrm{OC}$ & $16.0386 \pm 2.4136$ & $11.5646 \pm 1.8647$ & $12.4505 \pm 1.3535$ & $18.9959 \pm 3.0761$ & $12.8875 \pm 1.3175$ \\
\hline
\end{tabular}


TABLE SVI. P VALUES BETWEEN SOURCE PROFILES.

\begin{tabular}{lcccccccccccc}
\hline & CAF & CAR & CAS & TLL & CC & TP & PMX & PSN & QB & RTD & RTN & RP \\
\hline CAF & 1.000 & 0.148 & 0.288 & 0.002 & 0.002 & 0.001 & 0.107 & 0.075 & 0.013 & 0.081 & 0.021 & 0.016 \\
CAR & & 1.000 & 0.259 & 0.008 & 0.007 & 0.007 & 0.069 & 0.010 & 0.037 & 0.024 & 0.045 & 0.041 \\
CAS & & & 1.000 & 0.002 & 0.002 & 0.001 & 0.065 & 0.022 & 0.014 & 0.032 & 0.019 & 0.016 \\
TLL & & & & 1.000 & 0.320 & 0.038 & 0.104 & 0.027 & 0.087 & 0.032 & 0.166 & 0.884 \\
CC & & & & & 1.000 & 0.264 & 0.077 & 0.019 & 0.354 & 0.023 & 0.074 & 0.416 \\
TP & & & & & & 1.000 & 0.053 & 0.013 & 0.848 & 0.016 & 0.009 & 0.027 \\
PMX & & & & & & & 1.000 & 0.568 & 0.144 & 0.644 & 0.329 & 0.211 \\
PSN & & & & & & & 1.000 & 0.039 & 0.907 & 0.118 & 0.118 \\
QB & & & & & & & & 1.000 & 0.051 & 0.038 & 0.070 \\
RTD & & & & & & & & & 1.000 & 0.137 & 0.081 \\
RTN & & & & & & & & & & 1.000 & 0.170 \\
RP & & & & & & & & & & & 1.000 \\
\hline
\end{tabular}

